\title{
Discussion Paper No. 16-019 \\ Lender of Last Resort versus Buyer of Last Resort - The Impact of the European Central Bank Actions on the Bank-Sovereign Nexus
}

Viral Acharya, Diane Pierret, and Sascha Steffen

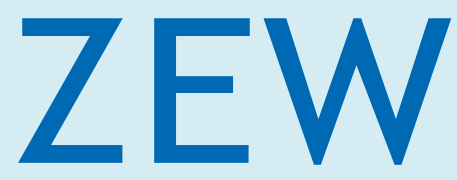

Zentrum für Europäische Wirtschaftsforschung $\mathrm{GmbH}$

Centre for European

Economic Research 


\title{
Discussion Paper No. 16-019 \\ Lender of Last Resort versus Buyer of Last Resort - The Impact of the European Central Bank Actions on the Bank-Sovereign Nexus
}

\author{
Viral Acharya, Diane Pierret, and Sascha Steffen
}

Download this ZEW Discussion Paper from our ftp server:

http://ftp.zew.de/pub/zew-docs/dp/dp16019.pdf

Die Discussion Papers dienen einer möglichst schnellen Verbreitung von neueren Forschungsarbeiten des ZEW. Die Beiträge liegen in alleiniger Verantwortung der Autoren und stellen nicht notwendigerweise die Meinung des ZEW dar.

Discussion Papers are intended to make results of ZEW research promptly available to other economists in order to encourage discussion and suggestions for revisions. The authors are solely responsible for the contents which do not necessarily represent the opinion of the ZEW. 


\title{
Lender of Last Resort versus Buyer of Last Resort - The Impact of the European Central Bank Actions on the Bank-Sovereign Nexus
}

\author{
Viral Acharya ${ }^{1}$, Diane Pierret $^{2}$, and Sascha Steffen ${ }^{3}$
}

This version: February 29, 2016

\begin{abstract}
In summer 2011, elevated sovereign risk in Eurozone peripheral countries increased the solvency risk of Eurozone banks, precipitating a run on their short-term debt. We assess the effectiveness of different European Central Bank (ECB) interventions that followed - lender of last resort vs. buyer of last resort - in stabilizing the European financial sector. We find that (i) by being lender of last resort to banks via the long-term refinancing operations (LTRO), ECB temporarily reduced funding pressure for banks, but did not help to contain sovereign risk. In fact, banks of the peripheral countries used the public funds to increase their exposure to risky domestic debt, so that when solvency risk in the Eurozone worsened the run of private short-term investors from Eurozone banks intensified. (ii) In contrast, ECB's announcement of being a potential buyer of last resort via the Outright Monetary Transaction program (OMT) significantly reduced the bank-sovereign nexus. The OMT increased the market prices of sovereign bonds, leading to a permanent reversal of private funding flows to Eurozone banks holding these bonds.
\end{abstract}

Keywords: Money market funds, repos, bank risk, sovereign debt, ECB.

JEL Classification: G01, G21, G28.

\footnotetext{
${ }^{1}$ C.V. Starr Professor of Economics, Department of Finance, New York University, Stern School of Business, 44 West 4th St., New York, NY 10012, email: vacharya@stern.nyu.edu, phone: +1 (212) 998 - 0354 fax: +1(212) 995 - 4256. Acharya is also a Research Affiliate of the CEPR and a Research Associate in Corporate Finance at the NBER.

${ }^{2}$ HEC - University of Lausanne, Institute of Banking and Finance, Extranef, 230, CH-1015 Lausanne (Switzerland), email: diane.pierret@unil.ch, phone: +41216926128.

${ }^{3}$ University of Mannheim - Business School, Center for European Economic Research (ZEW), L7, 1, 68161 Mannheim (Germany), email: steffen@zew.de, phone +49 621 1235-140, fax: +49 621 1235-223.

The authors thank Paolo Colla (discussant), Ruediger Fahlenbrach, Eric Jondeau, Loriano Mancini, Ralf Meisenzahl (discussant), Ouarda Merrouche, Erwan Morellec, Thomas Mosk, Artem Neklyudov, Kleopatra Nikolaou, Guillaume Roussellet, Batchimeg Sambalaibat, Oren Sussman (discussant), seminar participants at Copenhagen, CREST, ESMT, HEC Lausanne, Villanova University, and participants at the IBEFA 2015, IAES 2015, the SAFE-Deutsche Bundesbank-ESMT-CEPR 2015 conference, the AFGAP/ALMA 2015 summer conference, the Baffi Carefin Bocconi University 2015 conference, and the Federal Reserve Bank of Atlanta workshop on "The Role of Liquidity in the Financial System" for valuable comments and suggestions. The authors are grateful to Matthias Warnke for excellent research assistance. Financial support from Inquire Europe and the Volatility Institute at NYU Stern is gratefully acknowledged. Steffen is grateful to the Peter Curtius Foundation for financial support.
} 


\section{Introduction}

Europe has been in an extraordinary period of banking and sovereign stress since 2009 . The sovereign debt crisis that started in 2009-10 affected peripheral countries due to high sovereign or private sector debt and intimate sovereign-bank linkages (see Acharya and Steffen (2015)). This caused substantial instability in the European financial sector; solvency risk of banks increased, which in turn had immediate consequences on their funding liquidity. Funding liquidity risk peaked in summer 2011, when short-term investors „ran“ from European banks by massively withdrawing short-term funding. In particular, U.S. money market funds (MMFs) were the first group of investors to withdraw from banks in the euro area; U.S. prime MMFs holdings of Eurozone banks fell from 30 percent of their assets in May 2011 to 11 percent by December 2011 (ICI). ${ }^{1}$

The European Central Bank (ECB) reacted with a series of non-standard measures to deal with the sovereign debt crisis, such as engaging in the Long-Term Refinancing Operations (LTRO) in December 2011 and February 2012, and announcing the Outright Monetary Transactions program (OMT) in summer 2012. An important dimension along which these programs differed is whether the ECB acted as lender of last resort (LOLR) or buyer of last resort (BOLR). When acting as LOLR, e.g., in the LTRO, the ECB provided banks with funding liquidity in exchange for eligible collateral. When acting as BOLR, e.g., in the OMT, the ECB purchased or announced commitment to purchase Eurozone government bonds.

While a lender of last resort provides banks with liquidity, it can increase the risk of moral hazard if banks can use the public funds to increase their exposure to risky but eligible collateral because of, for example, gambling incentives (Acharya and Tuckman (2014)). In the context of the European sovereign debt crisis, under-capitalized banks would have incentives to increase holdings of risky domestic sovereign debt (Crosignani (2015)), especially once they are eligible collateral at the central bank (Drechsler et al. (2015); Hoshi and Kashyap (2015); Nyborg (2015)). Such response could segment the market for eligible collateral by making domestic banks the dominant holder of these assets, further strengthening the bank-sovereign nexus. While banks may be able to temporarily raise funding against eligible collateral, increase in riskiness of collateral, e.g., due to further sovereign stress, could aggravate funding risk due to the increased holdings of risky collateral.

In contrast, purchasing assets directly from the market does not segment the market preferentially towards banks and the credibility of such purchases in future stress periods

\footnotetext{
${ }^{1}$ ICI Research Perspective, January 2013.
} 
can bring in even non-bank financial firms to the market, allowing banks to delever by selling the risky assets. In the context of the European sovereign debt crisis, this would imply taking on some of the risks associated with sovereign debt holdings and providing liquidity to the markets at large, in turn weakening the domestic bank-sovereign nexus (Krishnamurthy et al. (2014)). By doing so, the asset purchases by the central bank could result in restoring the private funding for banks in a sustainable manner.

We study the effects of these two different ECB policy measures - LTRO versus OMT in stabilizing sovereign debt markets and funding markets for banks. In particular, we ask the following questions: In response to these unconventional ECB interventions, how did markets for sovereign debt react? How did banks adjust their sovereign bond holdings? How did ECB interventions affect bank access to short-term funding? And, were different central bank measures (LOLR vs. BOLR) equally effective?

In a first step, we analyze how ECB interventions affected sovereign and bank risk in the Eurozone since 2011. We investigate the impact of ECB interventions on (i) sovereign bond yields and sovereign credit default swap (CDS) spreads, (ii) banks' holdings of sovereign bonds, and (iii) bank equity prices and bank CDS spreads. We distinguish between (i) the peripheral countries Greece, Ireland, Italy, Portugal and Spain (GIIPS) - with a specific focus on Italy and Spain as the largest economies in the Eurozone periphery; (ii) euro area non-GIIPS countries; and (iii) European non-euro area countries. The last group is a control group where euro-area specific risks should be less relevant.

Using an event study methodology, we find that the LTRO did not affect much the sovereign risk of GIIPS countries. We do not find a significant reduction of sovereign yields around the announcement dates and allotment dates of the LTROs, consistent with the results of Krishnamurthy et al. (2014). Moreover, sovereign bond yields did not stabilize after LTROs. In fact, average GIIPS sovereign CDS spreads increased to their highest levels after the second LTRO. For example, sovereign CDS spreads of Spain and Italy increased, on average, by $48 \%$ between February 2012 and July $2012 .^{2}$

Banks from the peripheral countries used the LTRO funds to purchase domestic sovereign bonds. Italian and Spanish banks, for example, increased their domestic sovereign bond holdings by 49 EUR billion between the LTRO and the OMT program, increasing the domestic share in their sovereign bond portfolios from $79 \%$ to $83 \%$. The LTROs thus entrenched GI-

\footnotetext{
${ }^{2}$ In spring 2012, attention shifted to Italy and Spain amid a worsening situation across the Eurozone economies because of high levels of public debt and economic problems of these countries. Borrowing costs rose substantially and Spain eventually asked for bailout funds from the European Stability Mechanism (ESM) for its banking sector in June 2012.
} 
IPS sovereign bonds to GIIPS banks' balance sheets. Core European banks' balance sheets were stronger and in contrast these banks did not have the same incentives to purchase risky sovereign bonds. ${ }^{3}$ In other words, sovereign risk in the Eurozone became more concentrated in the portfolios of peripheral banks while core-European banks continued to reduce their GIIPS sovereign exposures.

Due to the elevated sovereign-bank linkages in the GIIPS countries, the increase in sovereign risk and sovereign bond yields following the LTRO allotments worsened the financial health of their domestic banks. Average 5-year CDS spread of Italian and Spanish banks, for example, increased by $47 \%$ in the time period between the second LTRO and the OMT program. But despite the rotation of sovereign risk from core to peripheral European banks, the LTROs did not make the worsening of the sovereign debt crisis less of a pan-European problem. In fact, non-GIIPS banks' CDS spreads also substantially increased after the second LTRO allotment. The 5-year CDS spreads of euro area non-GIIPS banks increased by $23 \%$. At the same time, the average equity prices of GIIPS banks and euro area non-GIIPS banks dropped by $60 \%$ and $36 \%$ respectively.

In striking contrast with the LTRO, we find that the OMT (introduced by Draghi's "Whatever it takes" speech in July 2012) significantly reduced the sovereign yields and CDS spreads of Italy and Spain. The OMT effectively eliminated the redenomination risk arising from the possibility that countries such as Italy and Spain could leave the euro area, which eventually increased the demand of GIIPS sovereign debt from non-GIIPS investors (Krishnamurthy et al. (2014)). Non-GIIPS banks started buying GIIPS sovereign debt again, reducing the GIIPS bank-sovereign nexus, and sovereign bond prices surged.

The drop in sovereign bond yields stabilized GIIPS banks and, consequently, we find a reduction of bank risk and increased bank performance following the OMT announcement. As discussed above, the GIIPS banks purchased a substantial amount of domestic sovereign bonds at low prices / high yields with LTRO money. The OMT increased the value of these bonds and increased the banks' financial health. We observe increasing equity prices, as well as decreasing CDS spreads of all Eurozone banks following the OMT. The average CDS cummulative abnormal changes of GIIPS banks are significantly negative around the OMT, suggesting that GIIPS banks benefited from a reduction of the GIIPS bank-sovereign nexus. Moreover, GIIPS and Eurozone non-GIIPS banks sold substantial amounts of domestic government bonds in the second half of 2013, realizing these gains and also strengthening their

\footnotetext{
${ }^{3}$ Acharya and Steffen (2015) identify moral hazard risk shifting of under-capitalized GIIPS banks as primary motive for sovereign bond purchases.
} 
book equity.

For our analysis of bank funding markets, we employ monthly data on U.S. MMF investments in European banks since November 2010, when the regulatory requirement of U.S. MMFs to report their portfolio composition started. Before analyzing the impact of ECB interventions on funding risk, we document the run of U.S. MMFs on European banks before the interventions. In the summer of 2011, European banks lost about $50 \%$ of their US dollar unsecured funding (-300 USD billions) via MMFs. We find that MMF investors withdraw more from Eurozone banks, compared to European non-euro area banks. GIIPS banks lost, on average, $45 \%$ of MMF funding each month, compared to $27 \%$ MMF outflows at Eurozone non-GIIPS and $2.7 \%$ outflows at non-euro area banks. This segmentation of MMF unsecured flows is consistent with MMF investors monitoring bank risk. We observe that MMF monthly outflows increase by $17 \%$ with a 100bps widening of bank CDS spreads. Similarly, MMF outflows are the largest for banks with large GIIPS sovereign debt exposures. Eventually, all GIIPS banks that previously had access to MMF funding lost access when sovereign risk peaked after the LTROs.

We document the importance of U.S. MMF flows in terms of funding risk of European banks (see also Chernenko and Sunderam (2014); Ivashina et al. (2012)). Even though MMFs are only a portion of European banks' short-term wholesale debt, they Granger cause aggregate short-term debt flows of these banks over the next month. Moreover, we show that banks that lost more (unsecured) MMF funding during the deepening of the sovereign debt crisis in 2011 were more likely to receive LTRO funding and also received larger amounts.

The LTRO liquidity injections by the ECB initially stopped the run and even prompted U.S. MMF flows from non-euro area banks to non-GIIPS euro area banks. However, the moral hazard behavior of GIIPS banks to load on domestic risky sovereign debt, which deepened the sovereign-bank linkages in the peripheral countries, also increased the risk for the Eurozone as a whole. Consequently, the run by U.S. MMFs on GIIPS and non-GIIPS euro area banks intensified after the second LTRO allotment in February 2012. Only a few banks holding safe U.S. collateral were able to substitute USD unsecured funding by USD secured funding via U.S. MMF repos following the LTRO.

The OMT program finally reversed the unsecured MMF flows. Between July and December 2012, U.S. MMFs increased unsecured funding of Eurozone banks by $89 \%$ and of non-Eurozone EU banks by $8 \%$. While the probability of losing access to U.S. MMFs remained large for Eurozone core banks $(6 \%)$ following the LTRO, this probability reduced to its lowest level following the OMT (1.8\%). Specifically, we find that MMF investors returned 
to the banks holding GIIPS sovereign bonds as OMT provided insurance for these bonds. Our results suggest that banks exposed to GIIPS sovereign debt were better able to recover access to U.S. MMFs, and that their funding risk - measured by the probability of losing access to U.S. MMFs - did not increase when holding GIIPS sovereign bonds in the post OMT period. ${ }^{4}$

In summary, while both lender of last resort and buyer of last resort interventions had temporary easing of bank funding risk, only the buyer of last resort intervention improved the prices of sovereign bonds. In turn, only the buyer of last resort intervention led to a reduction of the domestic sovereign-bank nexus, leading to a sustained improvement in bank funding conditions.

The rest of the paper proceeds as follows. Section 2 relates our paper to the existing literature and describes the institutional background as well as data used in our analysis. Section 3 investigates how ECB interventions affected sovereign bond prices. Section 4 focuses on effects on bank risk. In section 5, we investigate the MMF flows. We conclude in Section 6 with policy implications.

\section{Literature, institutional background and data}

\section{$2.1 \quad$ Related Literature}

Our paper is related to the literature investigating the bank-sovereign nexus. Acharya et al. (2014) model the interaction between sovereign and bank credit risk. Using CDS data, they show that bank bailouts were followed by increasing sovereign risk and increasing comovements between sovereign CDS and bank CDS spreads. In the model of Crosignani (2015), under-capitalized banks act as buyers of last resort for home public debt as they gamble for resurrection. Fahri and Tirole (2015) model the feedback loop between banks and sovereigns that allows for both domestic bank bailouts by the government and sovereign debt forgiveness. Gennaioli et al. (2014) present a model where government defaults should lead to declines in private credit, even more for countries where banks hold more government bonds.

Our paper is also related to the literature investigating the effect of monetary policy interventions by the ECB on sovereign bond yields. Evidence in some of these papers sug-

\footnotetext{
${ }^{4} \mathrm{We}$ also observe the maturity and yield of newly issued securities, and find that MMF investors considerably reduced the horizon of their investments at risky banks compared to low risk banks, increasing the cost of risk-taking through shorter maturities and larger yields. This is consistent with the presence of market discipline even in times of unconventional monetary policy measures of the ECB (see Appendix D).
} 
gests that the OMT announcement significantly lowered sovereign bond spreads (Szczerbowicz (2012), Altavilla et al. (2014), Krishnamurthy et al. (2014) and Saka et al. (2015)). Szczerbowicz (2012) find that the OMT measure lowered covered bond spreads and GIIPS sovereign yields. Krishnamurthy et al. (2014) investigate the channels causing the reduction in sovereign bond yields around the Securities Markets Program (SMP), the LTROs and the OMT. They find evidence consistent with a reduction of default risk, segmentation and redenomination risk among GIIPS countries. Saka et al. (2015) finds that the perceived commonality in default risk among peripheral and core Eurozone sovereigns increased after Draghi's "whatever-it-takes" announcement. Finally, Crosignani et al. (2015) find that the yield curve for the Portuguese sovereign bonds steepens after the LTRO announcement as Portugese banks increased their domestic holdings of shorter maturities more.

Another related strand of the literature analyzes whether non-standard policy measures by the ECB affected bank lending and the real sector. Analyzing the implications of the introduction of the full allotment concept (and the first LOLR intervention of the ECB) in October 2008, Acharya et al. (2015) find that the intervention reduced funding risk for all banks. It did, however, not result in better lending terms for all firms. Under-capitalized banks did not reduce loan spreads to the same extent compared to well-capitalized banks resulting also in lower asset growth and capital expenditures of borrowers of these banks. These results suggest that a LOLR policy that provides liquidity is less effective when the banking sector is weak. Acharya et al. (2015) and Ferrando et al. (2015) investigate the effects of OMT on extension of credit to European borrowers. Ferrando et al. (2015) find that SMEs in Europe are less likely to be credit constrained after OMT using survey data. Acharya et al. (2015) also find an increase in credit to European firms after OMT, which is used by firms to build cash positions but does not affect investment or employment.

We add to this literature in several ways. We highlight the differential effect of LOLR vs. BOLR policies: While providing liquidity to European banks, the LTRO transactions did not mitigate sovereign risk but further entrenched sovereign debt to banks' balance sheet. In contrast, the possibility to buy sovereign debt outright in the OMT substantially reduced sovereign risk. We further show how these interventions affect bank risk through sovereign-bank linkages. Importantly, we show the effect of LOLR policies on the behavior of short-term wholesale investors (U.S. MMFs) that are not protected by deposit insurance, and thus the effect on market discipline.

There is also a broader literature that investigates whether market discipline exists (and might be a possible governance mechanism complementing regulatory governance). This 
literature typically analyzes bond spreads of debt issued by banks and its sensitivity to bank risk (see, for example, Flannery and Sorescu (1996), or Acharya et al. (2014)). We add to this literature analyzing the sensitivity of fund flows of short-term wholesale investors as well as the sensitivity of maturity and yields of their investment to bank risk. More importantly, we show that market discipline remains during crises even amid a number of unconventional policy interventions of the ECB.

\section{$2.2 \quad$ ECB interventions}

Since 2010, the ECB conducted a series of unconventional policy measures to support a "dysfunctional market" and repair the monetary policy transmission mechanism. Our sample period starts in November 2010 with the disclosure regulation for U.S. MMFs, and, therefore, we consider ECB interventions during this period.

LTROs in detail. The ECB conducted two 3-year LTROs on December 21, 2011 and February 29, 2012. In the first LTRO (LTRO 1), the ECB allotted EUR 489 billion to 523 banks; in the second LTRO (LTRO 2), it allotted EUR 530 billion to 800 banks. The banks had to post collateral in exchange for funding under the LTRO programs and the interest on the funds was tied to the ECB policy rate.

The ECB already switched to full allotment in its regular main refinancing operations (MRO) in October 2008, for which banks paid the same interest rate as for LTROs. Rolling over weekly MROs is thus similar to borrowing under the LTRO. The latter, however, removes the uncertainty that the ECB switches back to fixed quantity allotment in its MROs. Acharya and Steffen (2015) document a substantial increase in home bias that was accelerated through the LTROs: in particular, Italian and Spanish banks purchased substantial amounts of domestic sovereign bonds while core European banks were reducing their exposure to GIIPS countries contributing to a further monetary and financial fragmentation of the euro area. Moreover, LTRO funding contributed to a further crowding out of real-sector lending through government bond purchases.

OMT program in detail. In response to the worsening of the sovereign debt crisis, ECB President Mario Draghi declared on July 26, 2012, during a conference in London: "Within our mandate, the ECB is ready to do whatever it takes to preserve the euro. And believe me, it will be enough." A few days later, on August 2, 2012, the ECB announced outright purchases of sovereign debt in secondary bond markets. On September 6, 2012, the ECB 
introduced and announced the key parameters of the OMT program. Under the program, the ECB could purchase unlimited amounts of euro area government bonds with maturities of one to three years when key conditions are met.

The country had to receive financial support from the European Stability Mechanism (ESM). The government had to comply with the reform efforts required by the respective ESM program. Moreover, the OMT program could only be activated if the country had regained complete access to private lending markets. Finally, the country's government bond yields had to be higher than what could be justified by the fundamental economic data. Compared to previous bond purchase programs, the ECB also did not make itself a senior claimant under the OMT program. If the ECB purchased sovereign bonds under the OMT, it would absorb the liquidity auctioning off an equal amount of one-week deposits at the ECB. As of end of 2015, the OMT program had not been used (i.e., the ECB did not purchase any sovereign bond under the OMT).

An important dimension along which LTRO and OMT interventions differed is whether the ECB acted as lender of last resort (LOLR) or buyer of last resort (BOLR). As LOLR, the ECB injected liquidity to the banks against eligible collateral. As BOLR, the ECB purchased or announced the possibility to purchase assets outright in secondary markets. Providing liquidity might prevent inefficient fire sales and help banks to deleverage and sell risky assets. However, it might also increase moral hazard as banks can use the liquidity to increase their exposure to risky assets because of, for example, gambling incentives. Purchasing assets directly reduces discretion of banks and thus moral hazard incentives (Acharya and Tuckman (2014)). Moreover, the conditionality associated with the OMT program also reduced moral hazard incentives of governments, which has effectively reduced the default risk of sovereign bonds (Krishnamurthy et al. (2014)). This in turn might have increased demand by non-bank investors and reduced the sovereign-bank nexus.

\subsection{Data sources}

The analysis of the consequences of ECB interventions on European banks starts with event studies in Section 3 and Section 4, linking those interventions with sovereign bond prices, sovereign bond CDS prices, and equity and CDS prices of European banks. All asset prices are collected from Bloomberg. We also collected data on sovereign bond holdings of European banks as disclosed by the European Banking Authority (EBA) in its stress tests and capitalization exercises at eight different dates from March 2010 until December 2013.

In Section 5, we study the access of European banks to U.S. money market funds. We 
start with a sample of 63 European banks that receive funding from U.S. MMF (see Table 2 in Appendix B). The 63 banks cover 15 European countries; 10 are Eurozone countries (including 3 GIIPS countries).

Monthly information on U.S. MMF investments at European banks is collected from the regulatory reports of U.S. MMFs available from the iMoneyNet database. As a consequence of the 2008-2009 financial crisis, the Securities and Exchange Commission (SEC) approved changes to Rule 2a-7 of the Investment Company Act of 1940 in 2010 and took other actions to strengthen the regulatory framework that governs MMFs. Following the SEC regulation, U.S. MMFs have to report monthly mark-to-market net asset value (NAV) per share of their portfolios on Form N-MFP, which is then published by the SEC.

From the N-MFP forms downloaded from iMoneyNet, we collect data on principal amounts, maturities, and yields of 15 different types of MMF securities (including CDs, repos, financial CPs) from November 2010 until August 2014 (46 months). The MMF data are collected for approximately 13,000 issuer names in the European banking industry and aggregated at the bank holding company level (63 banks).

We match MMF data for these 63 European banks with financial information (assets, capitalization, etc.) collected from SNL, market data (stock prices, market cap) from Bloomberg for the 31 banks that are publicly traded, 5-year CDS prices available for 34 banks, and EBA sovereign bond holdings available for 32 banks.

\section{Sovereign risk}

The ECB undertook a series of unconventional measures to restore financial stability in the European financial sector. We will see throughout this paper that the effectiveness of ECB interventions in restoring financial stability depends on the results of this section, namely whether the type of interventions we consider effectively reduced sovereign risk. In this section, we investigate the impact of ECB interventions on government bond yields and government bond CDS spreads. We then study the impact of ECB interventions on the equity and CDS prices of European banks in Section 4.

The European sovereign debt crisis has been characterized by a widening of the spread between the yields of German bunds and the yields of sovereign bonds of the peripheral countries of the Eurozone (we will call these countries "GIIPS" throughout, for Greece, Ireland, Italy, Portugal and Spain). We illustrate this difference in yields in Figure 1a, where we plot the average yields of 5-year government bonds of GIIPS countries, together 
with the average corresponding yield of Eurozone non-GIIPS countries (or Eurozone "core" countries for Austria, Belgium, Germany, France, and the Netherlands), and the average corresponding yield of European non-Eurozone countries (Denmark, Norway, Sweden, and the UK).

In Figure 1a, a reduction of GIIPS sovereign bond yields appears after Draghi speech in July 2012 and the announcement of the OMT in September 2012. We observe a similar pattern with the 5-year sovereign bond CDS prices in Figure 1b; the average CDS spread of GIIPS countries decreases after Draghi speech and the OMT announcement. We find in Table 1 (Panel A) that the average CDS spread of GIIPS countries decreases by $59 \%$ following Draghi speech. Not only the GIIPS countries benefited from the ECB acting as BOLR, the average CDS spreads of Eurozone core countries and non-Eurozone countries decrease by $64 \%$ and $59 \%$ respectively from July 2012 until December 2012. In contrast, the two 3-year LTRO transactions in December 2011 and February 2012 do not appear to have a significant impact on Eurozone sovereign yields or CDS prices. The risk of Italian and Spanish bonds even increases following the LTRO. Between the second LTRO allotment in February 2012 and Draghi speech in July 2012, the average CDS spread of Italy and Spain increases by $48 \%$.

To confirm these observations, we implement an event study analysis of sovereign bond yields and sovereign CDS spreads around ECB intervention dates. We calculate cumulative abnormal changes (CAR) of 5-year sovereign bond yields of Spain, Italy and Germany around 5 events that are reported in Table 2 (Panel A): (1) the announcement of the 3 -year LTRO (12-8-2011), (2) the allotment of the first LTRO tranche (12-21-2011), (3) the allotment of the second LTRO tranche (2-29-2012), (4) "Draghi speech" (7-26-2012), and (5) the OMT announcement (9-06-2012). Abnormal changes are derived from a market model adjusted for autocorrelation. The methodology for deriving abnormal changes and their variance is described in Campbell et al. (1997). ${ }^{5}$

Consistent with what we observe graphically, the EUR 1 trillion injected into the financial system in both LTRO transactions did not have a major effect on sovereign bond yields. This finding also coincides with the findings of Krishnamurthy et al. (2014). In contrast, we find a significant reduction of Spanish and Italian sovereign yields following Draghi speech, and a significant reduction of the Spanish sovereign yields after the OMT announcement. For

\footnotetext{
${ }^{5}$ The abnormal changes (resp. returns) in the market model adjusted for autocorrelation are derived from $A R_{i T+h}=r_{i T+h}-\left[\hat{\alpha}_{i}+\hat{\beta}_{i} r_{m T+h}+\hat{\varphi}_{i} r_{i T+h-1}\right]$, where $r_{i t}$ is the yield or spread change (resp. log-return) of asset $i, r_{m t}$ is the yield or spread change (resp. log-return) of the market index.
} 
example, the 2-day CAR of Spanish bonds around Draghi speech is $-0.58 \%$ and decreases to $-1.09 \%$ using the 5 -day CAR. The reduction in Italian sovereign yields is more modest ($0.41 \%) .{ }^{6}$ We find similar results for the event study on 5-year sovereign CDS spreads in Table 2 (Panel B); we observe a reduction of Spanish and Italian sovereign risk following Draghi speech and following the OMT announcement (with, again, a more pronounced impact on Spanish CDS spreads).

Overall, the results of this section help us to draw an important distinction between the effects of LOLR vs. BOLR interventions of the ECB; while the LOLR interventions have almost no impact on sovereign risk, BOLR interventions significantly reduced the sovereign risk of Italy and Spain.

\section{Solvency risk}

\subsection{Sovereign bond holdings}

ECB interventions gave incentives for banks to adjust their portfolios of sovereign bonds. This information is available from the several EBA disclosures on sovereign bond holdings of European banks from March 2010 until December 2013. We show this reallocation of the sovereign bond portfolio of European banks between different EBA disclosures in Table 4.

In Panel A, we report the evolution of domestic sovereign exposure (home exposure) of GIIPS, Italian and Spanish banks, as well as the evolution of GIIPS sovereign exposure of Eurozone core banks and non-Eurozone banks. Between the LTRO and the OMT (between December 2011 and June 2012), the home exposure of GIIPS banks increased by 55 EUR bn while non-GIIPS banks (Eurozone and non-Eurozone) decreased their exposure to GIIPS sovereign debt by 15 EUR bn. In particular, Italy and Spain increase their home exposure by 49 EUR bn following the LTRO. The trend is different following the OMT announcement (after June 2012), where all banks increase their exposure to GIIPS sovereign debt. During the three months following the OMT announcement, GIIPS banks increase their home exposure by 12 EUR bn. More importantly, Eurozone core banks stop reducing their exposure to GIIPS sovereign debt and start buying GIIPS sovereign bonds again; we find that Eurozone core banks increase their exposure to GIIPS sovereign debt by 4 EUR bn following the OMT.

In Panels B and C, we split the evolution of banks' sovereign bond exposures by maturity of their sovereign bond holdings. Panel B shows the evolution of sovereign bond holdings of

\footnotetext{
${ }^{6}$ We find similar results on 10-year sovereign bond yields and 2-year sovereign bond yield (see Appendix A). We find that sovereign CAR of Italy and Spain tend to be more significantly negative around the OMT than Draghi speech for the long end of the yield curve.
} 
short maturity (between 1 and 3 years), while Panel C shows the evolution of longer-term bond holdings (of maturity above 3 years). For both short-term and long-term bonds, we observe this change of trend in the evolution of the GIIPS exposure of non-GIIPS banks. Before the OMT announcement, non-GIIPS banks were selling sovereign bonds of GIIPS countries and therefore reducing their exposure to GIIPS sovereign debt. Following the OMT announcement, non-GIIPS banks start increasing again their exposure to GIIPS sovereign debt.

Overall this section shows a distinctive pattern in the evolution of GIIPS sovereign bond holdings following LOLR vs. BOLR interventions. Following the LTRO (ECB acting as LOLR), we observe a rotation of GIIPS sovereign bonds from non-GIIPS banks to GIIPS banks (i.e. an increase of home bias). Because the risk of GIIPS sovereign bonds is not reduced following the LTRO, what we observe is a rotation of risky assets from low risk to high risk banks. Risky banks used the LTRO funding provided by the ECB to increase their exposure to risky illiquid assets. LTRO therefore contributed to more fragmented sovereign bond markets and increasing bank-sovereign nexus in GIIPS countries.

Following the OMT (ECB acting as BOLR), all banks increased their exposure to GIIPS sovereign debt motivated by the reduction of sovereign bond yields and sovereign CDS of Italy and Spain in particular.

\subsection{Bank equity and CDS prices}

In this section, we assess the effect of ECB interventions on equity prices and CDS prices of European banks. We continue to differentiate between the effects of LOLR type vs. BOLR type interventions. We start by examining the evolution of average bank equity prices in Figure 2a, and the evolution of average bank CDS prices in Figure 2b. We observe that the pre-intervention trend is characterized by falling stock prices and increasing CDS spreads. While CDS spreads are the largest for GIIPS banks, the largest drop in equity prices takes place for Eurozone core banks in the summer of 2011 (-72\% between May and December 2011). ${ }^{7}$

Following an effective central bank intervention, we expect to see CDS prices (bank risk) falling and a stabilization of stock prices (bank performance). The 3-year LTRO achieves this outcome for a couple of months only. The effect is then reversed and the situation of the banking sector worsen after the second LTRO allotment. We quantify this reversal in Table 3 (Panel C), where average equity prices of GIIPS banks increase by $15 \%$ after the first

\footnotetext{
${ }^{7}$ Note that Greek banks are excluded from GIIPS banks, and Dexia is excluded from Eurozone core banks.
} 
LTRO transaction but decrease by $-60 \%$ after the allotment of the second LTRO tranche. Similarly, the average 5-year CDS spread of GIIPS banks (Panel A) decreases following the first LTRO tranche (-20\%), and increases between the second LTRO tranche and Draghi speech (25\%). The effects on 3-year CDS spreads (Panel B) are similar, albeit larger in amplitude due to the higher sensitivity of short-term CDS spreads. We obtain an even more pronounced reversal of the trend of CDS spreads of Italian and Spanish banks following the second LTRO allotment.

The effect of the LTRO only lasted until full allotment of LTRO money in February 2012. Once ECB LTRO money was allocated to banks, the stability of the European banking sector started to be compromised again due to uncertainty about future (public or private) short-term funding flows. The increased bank-sovereign nexus in GIIPS countries not only amplified the risk of GIIPS banks and GIIPS sovereign bonds, it also had negative effects on Eurozone non-GIIPS banks. We obtain similar trends in CDS and equity prices of Eurozone core banks to the ones observed for GIIPS banks. Average equity prices of Eurozone core banks decrease by $-36 \%$ between the second LTRO and Draghi speech, and their average 5-year CDS increase by $23 \%$ over the same period.

Only BOLR actions (Draghi speech and OMT announcement) led to a permanent stabilization of bank risk. We observe this permanent effect in Figure $2 \mathrm{~b}$ and in Table 3. The average equity return is $36 \%$ for GIIPS banks and $41 \%$ for core banks between Draghi speech (July 2012) and December 2012. The reduction of 5-year CDS prices during the same period is $-27 \%$ and $-45 \%$ for GIIPS and Eurozone core banks respectively.

The event study results in Table ?? describe a similar picture. In this Table, we show the average cumulative abnormal equity returns (Panel A) and the average cumulative abnormal CDS changes (Panel B) of GIIPS, Eurozone core, and European non euro area public banks around the same events as in Section 3. The event study methodology of bank equity returns (or bank CDS changes) is similar to the methodology of Section 3, where we simply replace the sovereign yield changes of a country by the returns on the equally-weighted bank equity (or bank CDS) portfolio. This methodology allows accounting for cross-sectional dependence in bank abnormal returns since the events we study are common to all banks, and therefore overlapping. Average cumulative abnormal returns are derived from a market model adjusted for autocorrelation in the portfolio returns.

We do not find any significant abnormal equity returns for GIIPS, Eurozone non-GIIPS or non Eurozone banks following the different ECB interventions (including both LOLR and BOLR type interventions). We however note that equity returns are negative around 
the LTRO announcement date (December 8, 2011), and positive for the other intervention announcements. Concerning bank risk, we find a significant increase in the CDS spreads of Eurozone core banks around the LTRO annoucement date. The abnormal 5-year CDS spread and 3-year CDS spread increase are 12.9 bps and 12.33 bps respectively, and are significant at the $5 \%$ level. Abnormal CDS spreads are negative around the other announcement dates for all banks, but are not significant at the 5\% level until the annoncement of the OMT details. Around the annoucement of the OMT, we find significant negative abnormal CDS spread changes for GIIPS banks (excluding Greek banks). The 2-day cummulative abnormal change in 5-year average CDS spread of GIIPS banks is -35.66 bps and is significant at the $1 \%$ level. The strongest reduction in risk of GIIPS banks is observed with their 3-year CDS spreads; the 2-day CAR around OMT is about -38.42 bps.

In Table 6, we report the results of cross-sectional regressions of CDS CARs on bank characteristics, including their holdings of GIIPS and Eurozone non-GIIPS sovereign bonds scaled by the banks' total assets. We find a significant reduction of the 2-day CDS CARs at banks with a larger exposure to GIIPS sovereign debt following Draghi speech and the announcement of OMT details. Overall, the results are consistent with a stabilization of the risk of banks holding GIIPS sovereign bonds, and GIIPS banks in particular benefiting from a reduction of the GIIPS bank-sovereign nexus following the annoucement of the OMT.

\section{$5 \quad$ Funding flows}

The Securities Exchange Commission (SEC) defines the U.S. Money Market Funds as "an option for investors to purchase a pool of securities that generally provided higher returns than interest-bearing bank accounts." U.S. MMFs are typically low risk investments with higher returns than U.S. deposits since unlike deposits, MMFs are not insured by the Federal Deposit Insurance Corporation (FDIC). U.S. MMFs are therefore subject to runs. Moreover, U.S. MMFs have incentives to closely monitor Eurozone banks and their exposure to Eurozone sovereign risk since U.S. MMFs do bear the downside risk of investing in Eurozone risky banks. $^{8}$ In the following section, we review descriptive statistics of U.S. MMF investments at European banks in Subsection 5.1, we document the run of U.S. MMFs on European banks in Subsection 5.2, and the importance of U.S. MMF funding during the sovereign debt crisis in Subsection 5.3. We then investigate the impact of ECB interventions on U.S. MMF investments in Subsection 5.4.

\footnotetext{
${ }^{8}$ They are also subject to stricter regulations regarding the risk of their porfolio since 2010 (following the run on U.S. MMFs during the financial crisis of 2008-2009).
} 


\subsection{Descriptive statistics of U.S. MMF investments at European banks}

The four most important securities in terms of outstanding amounts invested by U.S. MMFs at European bank include certificates of deposits (CD), financial company commercial papers (Fin CP), government agency repurchase agreements (Gvt Repo), and Treasury repurchase agreements (Treasury Repo). ${ }^{9}$ These four securities amount for between $75 \%$ and $86 \%$ of all securities invested at 63 European banks through U.S. MMFs between 2010 and 2014. U.S. MMFs constitute the largest source of US-Dollar lending for European banks and their subsidiaries. U.S. MMF repos are secured by U.S. collateral, in particular U.S. government agency collateral for government agency repos, and U.S. treasuries for Treasury repos. In the rest of the paper, we will refer to unsecured funding for CDs and financial CPs, and secured funding for government repos, treasury repos and other repos.

MMF investments at European banks decreased from 993 USD billion to 686 USD billion over the sample period, with a minimum of 529 USD billion in June 2014 (see Figure 3a). A strong end-of-quarter seasonality is driven by repo funding. Collins and Gallagher (2014) explain that this seasonality usually appears around corporate tax payment dates for the fund, which occur on the 15th of March, June, September, and December. Munyan (2014) however shows that the seasonality in repo investments is driven by the broker-dealer subsidiaries of non-US banks rather than their repo lenders as banks practice "window dressing" to appear safer at regulatory reporting dates.

In Figure 3b, we show the evolution of unsecured and secured funding invested at European banks from November 2010 until August 2014. A "run" appears on unsecured funding starting in April 2011, then CDs and financial CPs start flowing back to European banks in summer 2012. The trend in secured funding (repos) is reversed; some banks are able to increase their secured funding from April 2011 until June 2012, then repo investments decrease when banks regain access to unsecured funding. However, only 13 European banks have access to repos funding via U.S. MMFs, as these repos require high-quality U.S. collateral. Therefore, all banks were not able to substitute unsecured funding with repos in U.S. MMFs and the inflows of repo funding during the crisis also reflect a flight-to-quality toward U.S. collateral.

In the next sections, we will focus on unsecured funding flows; the run during summer 2011 and the fly back following ECB interventions. To differentiate between the impact

\footnotetext{
${ }^{9}$ We report some descriptive statistics of the principal amounts, maturities, and yields of MMF securities invested at European banks in Table 3 in Appendix B.
} 
of the two main ECB interventions (LTRO and OMT), we focus the following analysis on four different periods: the pre-crisis period from November 2010 until May 2011, the crisis period from June 2011 until December 2011, the post LTRO period from January 2012 until September 2012, and the post OMT period from October 2012 until August 2014.

\subsection{The unsecured "run" on European banks}

The hypothesis we formulate in this section is based on the theoretical literature explaining bank runs based on the strength of the bank's fundamentals (Allen and Gale (1998); Gorton (1988); Gertler and Kiyotaki (2010); Diamond and Rajan (2005), among others). If MMFs are sensitive to bank risk, we expect larger funding outflows at insolvent banks. In the context of the European sovereign debt crisis, insolvency is correlated to the exposure of a bank to risky sovereign bonds. The extent to which a bank is exposed to sovereign risk should influence its access to short-term funding. The consequence of banks increasing their exposure to their domestic debt (home bias) is a geographical segmentation over bank insolvency. So we should see that GIIPS banks lose more funding than Eurozone core banks, and that Eurozone banks lose more funding than non-Eurozone banks at the peak of the sovereign debt crisis in summer 2011.

H1 As U.S. MMFs ran from European banks, they did distinguish between Eurozone GIIPS banks, Eurozone core banks, and non-Eurozone banks. This segmentation is the consequence of home bias and MMF investors monitoring bank risk. The unsecured run of U.S. MMFs from European banks is a run on Eurozone banks. We show the total principal amount of unsecured funding invested in GIIPS banks, Eurozone core banks, and non-Eurozone banks in Figure 4. In the summer of 2011, we observe that Eurozone banks lose access to U.S. MMF unsecured funding, while non-Eurozone banks are able to maintain their unsecured funding. In particular, GIIPS banks completely lose access to unsecured funding via U.S. MMFs following the deterioration of the sovereign bond yields of Italy and Spain.

The average MMF flows at GIIPS banks, Eurozone core banks, and non-Eurozone banks reported in Table 7 confirm these observations. In this Table, we report the estimation results of the regression

$$
d F_{i t}=\varphi d F_{i t-1}+\sum_{\tau}\left[\alpha_{G I I P S, \tau} d_{G I I P S}+\alpha_{c o r e, \tau} d_{c o r e}+\alpha_{n o n E u r o, \tau}\right] d_{\tau}+\epsilon_{i t}
$$

where $d F_{i t}=\left(M M F_{i t}-M M F_{i t-1}\right) / M M F_{i t-1} ; M M F_{i t}$ is the average MMF principal amount 
invested at bank $i$ over a 3 -month window $[t-1, t+1] ; d_{\tau}$ is a dummy variable where $\tau$ refers to pre-crisis, crisis, post-LTRO, and post-OMT periods, $d_{\text {GIIPS }}$ indicates banks in the peripheral Euro area (GIIPS), and $d_{\text {core }}$ indicates banks in the core Euro area (Euro nonGIIPS). The evidence suggests that U.S. MMFs reduce their investments at risky Eurozone (particularly GIIPS) banks in summer 2011, while maintaining their investments at nonEurozone banks. We observe significant average monthly outflows of $-45 \%$ at GIIPS banks, and $-27 \%$ at Eurozone core banks between June 2011 and December 2011. In contrast, U.S. MMF funding at non-Eurozone banks is stable as the average monthly outflow $(-2 \%)$ is not significant at the $10 \%$ level.

We can show that this segmentation is the consequence of bank risk and exposure to GIIPS sovereign debt. We illustrate the impact of risk on funding in Figure 5, where we show the evolution of MMF funding at high risk versus low risk banks. A bank is classified as "high risk" (resp. "low risk") if its 5-year CDS price in November 2010 was above (resp. below) the median of all banks 5-year CDS prices in November 2010. In this Figure, we observe that unsecured funding flows out of European banks, and particularly high risk banks during the crisis. With a similar regression as in eq. (1), we find significant unsecured outflows at risky banks before ECB interventions.

\subsection{Unsecured U.S. MMF run triggers other runs and ECB inter- ventions}

U.S. money market funds were the first group of investors to withdraw funding from European banks in 2011. ${ }^{10}$ The results of Table 8 (Panel A) indicate that the U.S. MMF flows at European banks are correlated with other short-term funding flows. In particular, we show that one-month lagged U.S. MMF unsecured funding flows are correlated with the flows in debt securities with residual maturity of one year invested at the 28 largest banks of the European Union. ${ }^{11}$ In contrast, secured funding flows are not significant to predict the evolution of other debt securities flows. The results of this Table suggest that the run of unsecured funding and the recovery following ECB interventions is somewhat also present in other sources of funding at European banks. The Granger-causal relationship of MMF unsecured funding on 1-year debt securities is robust to controlling for 2-year maturity debt flows at EU-28 banks (since a fraction of the 2-year residual maturity debt will become 1-year debt the next month).

\footnotetext{
10"US money market funds warm to eurozone" (FT, February 28, 2013)

${ }^{11}$ Banks' short-term debt includes commercial papers, certificates of deposits and short-term notes with a maximum maturity of 12 months. Source: ESRB.
} 
Focusing on the crisis period, we also show that unsecured funding outflows in U.S. MMFs predict the demand for public funding; banks that experienced U.S. dollar outflows through U.S. MMFs during the crisis become more reliant on ECB secured funding though longterm refinancing operations. The negative correlation between the six-month U.S. MMF unsecured funding flows during the crisis (from June 2011 until December 2011) and the LTRO amount (including the two LTRO tranches) a bank received is illustrated in Figure $6 b^{12}$

In Table 8 (Panel B), we show that unsecured MMF outflows during the crisis predict the probability of receiving LTRO funding (Probit analysis), as well as the amount of LTRO funding received (OLS analysis). Unsecured U.S. dollar outflows at a bank during the crisis increase the probability of the bank to receive LTRO funding. We measure this effect with the following Probit regression

$$
\mathrm{P}\left(L T R O_{i}=1 \mid X\right)=\Phi\left(\alpha+\beta_{F} d F_{i, c r i s i s}\right)
$$

where $L T R O_{i}$ is a binary variable equal to one if bank $i$ received LTRO funding ( 2 tranches of LTRO combined), $X$ comprises all explaining variables included in the regression, and $\Phi(\cdot)$ is the standard normal c.d.f. The marginal effect of unsecured funding outflows on the probability of receiving LTRO funding is given by $-\phi\left(\beta_{F} * d F_{i, \text { crisis }}+\alpha\right) * \beta_{F}$, where $\phi(\cdot)$ denotes the standard normal p.d.f., and $d F_{i, c r i s i s}$ is the 6 -month unsecured funding flow at bank $i$ before the LTRO.

For the median bank (i.e. the bank with $d F_{i, c r i s i s}$ equal to the median of all banks unsecured crisis flows), the results in the first column of Table 8 (Panel B) indicate that the probability of receiving LTRO funding increases by $0.7 \%$ with an additional $1 \%$ outflow in the six month preceding the first LTRO. This effect does not appear to be large but it is conditional on the value of median unsecured funding outflows during the crisis that are already $73 \%$. Therefore, the probability of a bank to get access to LTRO funding increases by $0.7 \%$ with one additional percent outflow when the bank already lost $73 \%$ of its unsecured funding. The marginal effect of unsecured funding outflows is still significant and of similar magnitude $(0.6 \%)$ when we control for the change in non-deposit liabilities of the bank in the regression. Finally, LTRO funding is also explained by the risk of the bank through its CDS spread and its exposure to GIIPS sovereign debt; the LTRO probability of the median bank increases by $26 \%$ with a 100 bps CDS spread increase, and by $16 \%$ with an increase of

\footnotetext{
${ }^{12}$ The amount of LTRO funding a bank received is hand collected from press articles. The LTRO numbers collected are consistent with results of Morgan Stanley LTRO survey of March 1, 2012.
} 
$0.01 \%$ of the ratio of GIIPS exposure to total assets. ${ }^{13}$

Ultimately, ECB liquidity injected through the LTRO helped stopping the run in U.S. MMFs: in Figure 6a, we observe that the aggregate unsecured funding outflow at European banks stops when the ECB started injecting liquidity through its LTRO in December 2011.

\subsection{The impact of LTRO and OMT on MMF funding flows}

H2: LTRO stopped the run at Eurozone core banks, but did not help in restoring access to private unsecured funding markets. Following the first LTRO allotment, private short-term funding starts flowing back to Eurozone core banks, and flowing out of non-Eurozone banks. We report the unsecured U.S. MMF flows by region after the first and second LTRO alloments in Table 9 (Panel A). This table shows that U.S. MMFs invest an additional 14 USD bn $(+19 \%)$ in unsecured securities at Eurozone core banks between the first LTRO and second LTRO allotment (December 2011 to February 2012), while 27 USD bn $(-16 \%)$ of unsecured funding flows out of European non-Eurozone banks during the same period.

The first LTRO allotment stopped the run in the euro area by moving unsecured funds from non-Eurozone to Eurozone core banks. GIIPS banks however continue to lose access to U.S. MMFs. Banco Santander is the only GIIPS bank that kept access to unsecured funding at the time of the first LTRO allotment. The bank loses access after the second LTRO allotment, and will be the only GIIPS bank to recover access to U.S. MMFs during our sample period.

The reversal of fund flows at Eurozone core banks did not last long. After the second LTRO allotment in February 2012, all banks (Eurozone and non-Eurozone banks) lose access to unsecured funding again, following the deterioration of bank CDS spreads. Eurozone and non-Eurozone banks respectively lose 19 USD bn (-21\%) and 28 USD bn (-19\%) in unsecured funding between February 2012 (second LTRO allotment) and July 2012.

From the results of regression (1) in Table 7, we do not find significant average unsecured flows to Eurozone banks from January 2012 until September 2012 (probably due to the reversal of MMF flows following the second LTRO allotment). However, it appears that some Eurozone core banks were able to substitute USD unsecured funding with USD secured funding during this period. In Table 7, we find signficant average monthly repo inflows of $0.9 \%$ for Eurozone banks in the post LTRO period. Table 9 (Panel C) indicate inflows

\footnotetext{
${ }^{13}$ These variables are however not jointly significant to predict LTRO funding as they are highly correlated (e.g. the correlation between unsecured outflows and GIIPS exposure is 0.87 ).
} 
of 1 USD bn and 9 USD bn at Eurozone core banks and non-Eurozone banks respectively following the first LTRO allotment. Secured funding flows at Eurozone bank are however reversed after the second LTRO allotment.

\section{H3: OMT helped Eurozone banks to recover access to private unsecured funding.} From Figure 4, we observe that a permanent reversal of U.S. MMF flows to Eurozone banks starts in July 2012, following Mario Draghi speech. Between July and December 2012, U.S. MMFs invested 61 USD bn unsecured at Eurozone core banks (and a additional 1 USD bn at Banco Santander), increasing the unsecured principal amount invested at Eurozone banks by $89 \%$. The short-term investments at Eurozone banks are not a reallocation of U.S. MMF portfolio from non-Eurozone banks to Eurozone banks; unsecured funding also increases at non-Eurozone banks by 11 USD bn $(+8 \%)$.

Repo outflows also indicate that the flight to quality toward U.S. collateral is reduced with OMT. Repo investments by U.S. MMFs is reduced by 72 USD bn (-40\%) at Eurozone banks, and by -10 USD bn (-6\%) at non-Eurozone banks from July 2012 until December 2012. Repo outflows at Eurozone banks are consistent with unsecured funding coming back, and these banks increasing their exposure to GIIPS and Eurozone sovereign debt.

Our next two hypotheses are motivated by Diamond and Rajan (2001) observing that financial fragility - banks being subject to runs - is a desirable characteristic of banks. If banks cannot fail, there will be no market discipline (Bliss and Flannery (2002); Rochet and Vives (2004)). ECB LTRO and OMT could potentially achieve the outcome by implicitly insuring the portion of uninsured non-deposit funding at a bank. In particular, wholesale funding markets could be subject to a weakening of market discipline following the OMT when private funds returned to the (risky) banks that were intially experiencing runs. Our results suggest that the reversal of fund flows to risky banks is not a sign of impaired market discipline, but the consequence of increasing sovereign bond prices following the OMT announcement.

\section{H4: Following the OMT, unsecured funding flows back to risky banks (only)} because these banks hold GIIPS sovereign bonds. Following the OMT, the impact of risk on funding is reversed as risky banks recover part of their secured and unsecured funding. In particular, Figure 5 shows that unsecured funding flows back to risky banks following the announcement of the OMT. To measure the incremental effect of bank risk on funding flows, we use the cross-sectional information from bank CDS prices and bank sovereign exposures 


$$
d F_{i t}=\varphi d F_{i t-1}+\sum_{\tau}\left[\beta_{1 \tau} C D S_{i, \tau}+\beta_{2 \tau} \frac{\text { GIIPS holdings } s_{i, \tau}}{T A_{i, \tau}}+\alpha_{\tau}\right] d_{\tau}+\epsilon_{i t}
$$

where $C D S_{i, \tau}, G I I P S$ holdings $_{i, \tau}, T A_{i, \tau}$ are respectively the last available 5-year CDS price, GIIPS sovereign gross direct exposure, and total assets of bank $i$ before the period $\tau$ starts. We report the estimation results of this regression in Table 10.

Without controlling for the GIIPS exposure, we find that the impact of risk, as measured by CDS spreads, is negative and significant for unsecured funding before and during the crisis, not significant during the LTRO, and positive after the OMT. ${ }^{14}$ Banks with higher CDS prices experience larger outflows on their unsecured funding during the crisis; a widening of $100 \mathrm{bps}$ of the CDS spread produces an incremental monthly outflow of $-17 \%$. After the OMT, the impact of risk on unsecured funding flows becomes significantly positive; the incremental unsecured inflow is $2 \%$ for a 100 bps CDS spread increase.

The positive post-OMT effect of risk on funding remains significant when we control for the crisis unsecured outflows in the regression. Therefore, the MMF unsecured funding inflow following the OMT is not only an endogenous fly back to risky banks. Post OMT inflows are not only an effect of risky banks recovering their pre-crisis funding; the cross-sectional variation in unsecured flows is also positively correlated with the cross-sectional variation in bank risk.

Part of the risk information contained in CDS spreads that explains funding flows comes from the exposure of banks to risky sovereign debt. Holding the CDS spread fixed, we find that a $1 \%$ increase of the ratio of the bank's GIIPS sovereign bond holdings to its assets (GIIPS holdings $s_{i, \tau} / T A_{i, \tau}$ ) produces an incremental average monthly outflow of $-3 \%$ during the crisis period.

After the OMT, inflows to risky banks are almost exclusively driven by the exposure of a bank to GIIPS sovereign debt. Without controlling for the CDS spread, monthly unsecured funding flows increase by $5 \%$ with a $1 \%$ increase of the ratio measuring the GIIPS exposure of a bank..$^{15}$ We also show in Table 10 that the positive post-OMT impact of CDS spreads

\footnotetext{
${ }^{14}$ We also find that secured funding is not sensitive to risk during the crisis as U.S. MMF repos are secured by U.S. collateral, but risk has a positive impact on repo flows following the OMT.

${ }^{15}$ The findings linking GIIPS exposure to USD funding are confirmed by cross-sectional regressions of banks' bond portfolio exposures against their MMF flows 3 months and 6 months after each EBA measurement date. We find that the exposure of banks to GIIPS debt has a significant impact on their future MMF flows (see Table 5 in Appendix C). In early exercises (December 2010 and September 2011), the exposure to risky sovereign debt has a negative impact on MMF investments. But in the last two exercises (December 2012 and June 2013), this parameter has the opposite sign such that banks with higher exposure to GIIPS debt also experience higher MMF inflows in the next months.
} 
becomes insignificant when we include the GIIPS exposure of a bank in the regression. We conclude that the relevant information in bank CDS spreads that explains funding inflows purely comes from banks' exposure to GIIPS sovereign debt following the OMT. In constrast, unsecured outflows from risky banks during the crisis are only partly driven by the exposure of a bank to GIIPS sovereign debt; leverage was another important risk measure guiding unsecured outflows during the sovereign debt crisis. ${ }^{16}$

Most of the results we find in this section hold when we reproduce the results on Eurozone core banks only (see Table 4 in Appendix C). This allows us to highlight the impact of the risk channel in determining access to U.S. MMFs. Similarly, we can show that the positive impact of bank risk on unsecured funding following the OMT announcement is robust to country fixed effects, common factors (Table 8 in Appendix C), and the interaction between country and period fixed effects.

H5: Following the OMT, bank funding risk does not increase with the bank's exposure to GIIPS sovereign debt. The unsecured outflows we observe at Eurozone banks during the crisis are the result of banks losing access to some money market funds for their unsecured funding in US dollar. We further explore access to U.S. MMFs in Table 11, using three different variables: (i) the difference in the number of securities invested at a bank, (ii) the probability of completely losing access to U.S. MMF unsecured funding, and (iii) the probability of losing access to one fund.

The results of Panel A of Table 11 are obtained from the regression

$$
d N_{i t}=\varphi d N_{i t-1}+\sum_{\tau}\left[\alpha_{G I I P S, \tau} d_{G I I P S}+\alpha_{\text {core }, \tau} d_{\text {core }}+\alpha_{\text {nonEuro }, \tau} d_{\text {nonEuro }}\right] d_{\tau}+\epsilon_{i t}
$$

where $d N_{i t}=\left(N_{i t}-N_{i t-1}\right)$ and $N_{i t}$ is the average number of U.S. MMF securities invested at bank $i$ over a 3 -month window $[t-1, t+1] ; d_{\tau}$ is a dummy variable where $\tau$ refers to precrisis, crisis, post-LTRO, and post-OMT periods, $d_{\text {GIIPS }}$ indicates banks in the peripheral Euro area (GIIPS), $d_{\text {core }}$ indicates banks in the core Euro area (Euro non-GIIPS), and $d_{\text {nonEuro }}$ indicate banks in the European non-Euro area.

Eurozone core banks are the banks that lose the most securities during the crisis; they lose an average of 7.3 U.S. MMF unsecured securities per month, compared to 3.6 securities lost in average at GIIPS banks. In contrast, unsecured funding at non-Eurozone banks is stable during the crisis, as the average number of securities lost in a month is not signifi-

\footnotetext{
${ }^{16}$ We explore other risk measures like market leverage $(\mathrm{Lvg})$, or the Tier 1 capital ratio $(\mathrm{T} 1 \mathrm{CR})$ in Table 7 (Appendix C).
} 
cantly different from zero. Before summer 2011 (the "pre-crisis" period), U.S. MMFs already penalize banks for their risk taking by not renewing their short-term funding contracts. Increasing the fraction of GIIPS sovereign bond holdings of a bank to its total assets by $1 \%$, we find that a bank loses an average of 122 securities a month. ${ }^{17}$

Following ECB interventions, the average number of new securities invested at Eurozone core banks increases. The average number of unsecured securities invested at Eurozone banks increases by 1 each month after the LTRO, and by 0.7 after the OMT. Moreover, the number of securities invested at banks increases with their exposure to GIIPS sovereign debt after the OMT. We find that a bank gains an average of 41 unsecured securities per month with an increase of $1 \%$ of its fraction of GIIPS sovereign bond holdings to the bank total assets.

Some banks completely lose access to U.S. money market funds during the crisis. In Table 11 (Panel B), we show the results of a Probit regression that explains the probability for a bank to lose access to U.S. MMFs. Since only 13 banks have access to secured funding and since these banks never completely lose access to repos, we concentrate on banks losing access to unsecured funding via U.S. MMFs. The dependent variable is equal to one at date $t$ if the bank had access to unsecured funding in month $t-1$ and lost its access to unsecured funding during month $t$.

The results in Table 11 show that the probability of completely losing access to U.S. MMF unsecured funding ( $\mathrm{P}$ (losing access to all funds) ) is the highest for GIIPS banks $(15 \%)$ during the crisis, compared to core Eurozone banks (8\%) or non-Eurozone banks $(1.8 \%)$. Indeed, most GIIPS banks lose access to unsecured funding before the first LTRO allotment. The probability of Eurozone core banks of losing access to unsecured U.S. MMFs is $6 \%$ after the LTRO, and reduces to its lowest level (1.8\%) following the OMT. All these probabilities are significantly different from $50 \%$ at the $1 \%$ level.

The probability of losing access to a particular fund in month $t$ when the bank had access to this fund in month $t-1$ ( $\mathrm{P}($ losing access to one fund $))$ is always larger than the probability of completely losing access to U.S. MMFs (P(losing access to all funds)). ${ }^{18}$ The Probit regression describing access to a fund is

$$
\mathrm{P}\left(Y_{i j t}=1 \mid X\right)=\Phi\left(\sum_{\tau}\left[\alpha_{G I I P S, \tau} d_{G I I P S}+\alpha_{c o r e, \tau} d_{c o r e}+\alpha_{n o n E u r o, \tau} d_{n o n E u r o}\right] d_{\tau}\right)
$$

where $Y_{i j t}$ is a binary variable equal to one if fund $j$ invested unsecured in bank $i$ in month $t-1$ and ceased investing unsecured in that bank in month $t, X$ comprises all explaining

\footnotetext{
${ }^{17}$ We find similar results where banks are classified according to their CDS prices in November 2010.

${ }^{18}$ We study the probability of gaining access to U.S. MMFs in Table 6 (Appendix C).
} 
variables included in the regression, and $\Phi(\cdot)$ is the standard normal c.d.f.

During the crisis, the probability $\mathrm{P}\left(Y_{i j t}=1 \mid X\right)$ is the highest for GIIPS banks (35\%), compared to core Eurozone and non-Eurozone banks (21\% and $12 \%$ respectively). After the LTRO, the probability of losing access to one fund for a GIIPS bank is not significantly different from $50 \%$, while this probability is $6 \%$ for Eurozone core banks and $0.74 \%$ for non Eurozone banks. The probability of a GIIPS bank (Banco Santander) to lose access to one fund is the lowest $(5 \%)$ following the OMT, and is lower than the probabilty of Eurozone core banks and non-Eurozone banks (11\% and $9 \%$ respectively).

We derive the marginal effect of an increase in the GIIPS exposure for the "median bank" (i.e., a bank that holds the cross-sectional median exposure to GIIPS sovereign debt) on its probability of losing access to unsecured funding. While increasing the GIIPS exposure has the largest positive impact on the probability of losing access to U.S. MMFs following the LTRO, this marginal effect of the bank GIIPS exposure on losing access to unsecured funding is not significantly different from zero following the OMT. This conclusion holds for both the probability of losing access to one fund and the probability of losing access to all U.S. money market funds.

Overall, this section suggests that the banks that are holding GIIPS sovereign bonds following the OMT are better able to recover access to unsecured funding. Not only these banks experience larger unsecured inflows, we also find that their funding risk - measured by the probability of losing access to U.S. MMFs - does not increase when holding the GIIPS sovereign bonds following the OMT.

Finally, we show (in Appendix D) that MMF investors considerably reduced the horizon of their investments at risky banks (or banks exposed to GIIPS sovereign debt) compared to low risk banks, increasing the cost of risk-taking through shorter maturities and larger yields. Low risk banks are rewarded by longer maturities for their new unsecured funding securities without a corresponding increase in yields. The gap in maturities between new securities invested at low risk vs. high risk banks widens suggesting that MMF investors only return short-term to high risk banks. Our results therefore do not suggest a weakening of market discipline in wholesale funding markets as an unintended consequence of the OMT program. 


\section{Conclusion}

We assess the effectiveness of unconvential interventions of the European Central Bank (ECB) in restoring financial stability in the Eurozone following the peak of the sovereign debt crisis in summer 2011. A central result of the paper is that how ECB intervened mattered in particular, whether the ECB acted as lender of last resort (e.g., LTRO in December 2011 and February 2012) or buyer of last resort (e.g., OMT in summer 2012).

While the LTRO did not affect sovereign risk of GIIPS countries, the OMT did significantly reduce the sovereign yields and sovereign credit default swap spreads of Italy and Spain. Moreover, while the LTRO did reduce immediate funding risk for banks, we show that it aggravated the bank-sovereign nexus by giving incentives to GIIPS banks to increase their holdings of domestic sovereign bonds. Consequently, when sovereign risk increased again in the peripheral countries after the LTROs, the financial health of Eurozone banks worsened and the run of short-term private creditors intensified. In contrast, the OMT led to a reduction of the domestic bank-sovereign nexus. By effectively increasing the market prices of sovereign bonds, the OMT gave incentives for all banks to buy these bonds and improved the asset side of banks exposed to GIIPS sovereign debt. The consequence was a permanent reversal of private funding flows towards Eurozone banks following the OMT.

Overall, our findings suggest that the effectiveness of unconventional central bank interventions should not only be assessed in terms of a reduction of immediate funding risk for banks. Instead, we should also carefully assess the effects of these interventions on the asset side of banks. Central bank interventions can aggravate a crisis situation when they increase moral hazard by giving banks incentives to hold onto or expand their holdings of troubled assets. Specifically, without an adequate recapitalization of distressed banks, the lender of last resort interventions can entrench banks with risky assets making them more vulnerable to runs if risky assets worsen in quality. In contrast, buyer of last resort interventions provide liquidity to the market at large and can credibly improve bank fundamentals and stabilize their short-term funding markets.

\section{References}

Acharya, V., D. Anginer, and A. Warburton (2014). The end of market discipline? investor expectations of implicit government guarantees. Working Paper.

Acharya, V., I. Drechsler, and P. Schnabl (2014). A pyrrhic victory? bank bailouts and 
sovereign credit risk. Journal of Finance 69(6), 2689-2739.

Acharya, V., T. Eisert, C. Eufinger, and C. Hirsch (2015). Whatever it takes: The real effects of unconventional monetary policy. working paper.

Acharya, V. and S. Steffen (2015). The "greatest" carry trade ever?: Understanding eurozone bank risks. Journal of Financial Economics 115(2), 215-236.

Acharya, V. and B. Tuckman (2014). Unintended consequences of LOLR facilities: the case of illiquid leverage. IMF Economic Review 62(4), 606-655.

Allen, F. and D. Gale (1998). Optimal financial crises. Journal of Finance 53:4, 1246-1284.

Altavilla, C., D. Giannone, and M. Lenza (2014). The financial and macroeconomic effects of OMT announcements. CEPR Discussion Paper No. DP10025.

Bliss, R. and M. Flannery (2002). Market discipline in the governance of U.S. bank holding companies: Monitoring vs. influencing. European Finance Review 6, 361-395.

Campbell, J., A. Lo, and C. MacKinlay (1997). The Econometrics of Financial Markets. Princeton University Press.

Chernenko, S. and A. Sunderam (2014). Frictions in shadow banking: Evidence from the lending behavior of money market mutual funds. Review of Financial Studies 27(6), $1717-1750$.

Collins, S. and E. Gallagher (2014). The real effects of a manufactured crisis: Money market funds and the summer of 2011.

Crosignani, M. (2015). Why are banks not recapitalized during crises? ONB Working Paper no. 203.

Crosignani, M., M. Faria-e Castro, and L. Fonseca (2015). The (unintended?) consequences of the largest liquidity injection ever. NYU working paper.

Diamond, D. and R. Rajan (2001). Liquidity risk, liquidity creation, and financial fragility: A theory of banking. Journal of Political Economy 109(2), 287-327.

Diamond, D. and R. Rajan (2005). Liquidity shortages and banking crises. Journal of Finance 60:2, 615-647. 
Drechsler, I., T. Drechsel, D. Marques-Ibanez, and P. Schnabl (2015). Who borrows from the lender of last resort? Journal of Finance.

Fahri, E. and J. Tirole (2015). Deadly embrace: Sovereign and financial balance sheets doom loops. NBER Working Paper No. 21843.

Ferrando, A., A. Popov, and G. Udell (2015). Sovereign stress, unconventional monetary policy, and SME access to finance. Working Paper.

Flannery, M. and S. Sorescu (1996). Evidence of bank market discipline in subordinated debenture yields: 1983-1991. Journal of Finance 51(4), 1347-1377.

Gennaioli, N., A. Martin, and S. Rossi (2014). Sovereign default, domestic banks, and financial institutions. Journal of Finance 69(2), 819-866.

Gertler, M. and N. Kiyotaki (2010). Financial intermediation and credit policy in business cycle analysis. In B. Friedman and M. Woodford (Eds.), Handbook of Monetary Economics, pp. 547-599. Elsevier.

Gorton, G. (1988). Banking panics and business cycles. Oxford Economic Papers 40:4, $751-781$.

Hoshi, T. and A. Kashyap (2015). Will the U.S. and europe avoid a lost decade? lessons from japan's post crisis experience. IMF Economic Review 63, 110-163.

Ivashina, V., D. S. Scharfstein, and J. C. Stein (2012). Dollar funding and the lending behavior of global banks. SSRN Electronic Journal.

Krishnamurthy, A., S. Nagel, and A. Vissing-Jorgensen (2014). ECB policies involving government bond purchases: Impact and channels.

Munyan, B. (2014). Regulatory arbitrage in repo markets. Working paper.

Nyborg, K. (2015). Central bank collateral frameworks. Swiss Finance Institute Research Paper Series N. 15-10.

Rochet, J.-C. and X. Vives (2004). Coordination failures and the lender of last resort: was Bagehot right after all? Journal of the European Economic Association 2:6, 1116-1147.

Saka, O., A.-M. Fuertes, and E. Kalotychou (2015). ECB policy and eurozone fragility: Was De Grauwe right? Journal of International Money and Finance 54, 168-185. 
Szczerbowicz, U. (2012). The ECB unconventional monetary policies: have they lowered market borrowing costs for banks and governments? Working Paper. 


\section{Table 1: Impact of ECB interventions on sovereign CDS spreads and sovereign yields}

This table reports the percentage change in average 5-year sovereign CDS spread (Panel A), average 5-year sovereign bond yield (Panel B), average 10-year sovereign bond yield (Panel C), and average 2-year sovereign bond yield (Panel D), following LTRO1 (12-21-2011), LTRO2 (02-29-2012), and OMT (07-26-2012). Note that "OMT" corresponds to the date of M. Draghi' speech. IS stands for Italy and Spain. GIIPS excludes Greece.

Panel A: Change in average 5-yr sovereign CDS (\%)

\begin{tabular}{l|rrr}
\hline & GIIPS (IS) & Euro nonGIIPS & nonEuro \\
\hline LTRO1 - LTRO2 & $-8(-13)$ & -17 & -23 \\
LTRO2 - OMT & $-1(48)$ & -12 & -7 \\
post OMT & $-59(-55)$ & -64 & -49
\end{tabular}

Panel B: Change in average 5-yr sovereign yield (\%)

\begin{tabular}{l|rrr}
\hline & GIIPS (IS) & Euro nonGIIPS & nonEuro \\
\hline LTRO1 - LTRO2 & $-19(-33)$ & -24 & -16 \\
LTRO2 - OMT & $4(56)$ & -50 & -49 \\
post OMT & $-58(-49)$ & -54 & 12
\end{tabular}

Panel C: Change in average 10-yr sovereign yield (\%)

\begin{tabular}{l|rrr}
\hline & GIIPS (IS) & Euro nonGIIPS & nonEuro \\
\hline LTRO1 - LTRO2 & $-5(-15)$ & -8 & 1 \\
LTRO2 - OMT & $6(29)$ & -29 & -36 \\
post OMT & $-26(-29)$ & -15 & 12
\end{tabular}

Panel D: Change in average 2-yr sovereign yield (\%)

\begin{tabular}{l|rrr}
\hline & GIIPS (IS) & Euro nonGIIPS & nonEuro \\
\hline LTRO1 - LTRO2 & $-39(-58)$ & -54 & 18 \\
LTRO2 - OMT & $6(84)$ & -93 & -45 \\
post OMT & $-71(-67)$ & -122 & 12
\end{tabular}




\section{Table 2: Sovereign event study}

This table reports in Panel A: the 2-day [-1;1] cumulative abnormal changes in 5-year bond yields of Spain, Italy and Germany surrounding various interventions from the European Central Bank (ECB). In Panel B: the 2-day [-1;1] cumulative abnormal changes in 5-year sovereign CDS spreads of Spanish bonds, Italian bonds and German bunds surrounding various ECB interventions. These are: the LTRO announcement (December 8, 2011), LTRO 1 (December 21, 2011), LTRO 2 (February 29, 2012), Draghi speech (July 26, 2012), and the announcement of the OMT details (September 6, 2012). The evidence in Panel A is based on market model and autocorrelation adjusted abnormal bond yield changes. We use the JPM EU Sovereign Bond Index as the benchmark bond market index in computing these abnormal changes. The evidence in Panel B is based on market model and autocorrelation adjusted abnormal CDS changes. We use the Markit iTraxx SovX Western Europe index as the benchmark CDS market index in computing these abnormal changes. T-statistics are in parentheses. ${ }^{* * *},{ }^{* *}$, and $*$ indicate significance at the 1\%, 5\%, and $10 \%$ levels, respectively.

\begin{tabular}{l|ccc|ccc} 
& \multicolumn{3}{|c}{ Panel A: CAR of 5-yr Sovereign yields } & \multicolumn{3}{c}{ Panel B: CAR of 5-yr Sovereign CDS } \\
\hline & Spain & Italy & Germany & Spain & Italy & Germany \\
\hline LTRO & 19.069 & 25.935 & -4.226 & 19.345 & $37.984^{* *}$ & -1.373 \\
$12-8-2011$ & $(1.199)$ & $(1.304)$ & $(-0.445)$ & $(1.468)$ & $(2.519)$ & $(-0.418)$ \\
& & & & & & \\
LTRO 1 & 13.778 & 18.024 & -0.821 & 8.206 & -14.052 & -1.060 \\
$12-21-2011$ & $(0.856)$ & $(0.891)$ & $(-0.087)$ & $(0.593)$ & $(-0.894)$ & $(-0.313)$ \\
& & & & & & \\
LTRO 2 & -4.559 & $-41.345^{*}$ & 11.351 & -3.636 & -20.430 & -2.815 \\
2-29-2012 & $(-0.270)$ & $(-1.921)$ & $(1.231)$ & $(-0.256)$ & $(-1.257)$ & $(-0.820)$ \\
& & & & & & \\
Draghi speech & $-58.060^{* * *}$ & $-40.585^{*}$ & $15.444^{*}$ & $-54.407^{* * *}$ & $-38.906^{*}$ & -2.981 \\
7-26-2012 & $(-2.728)$ & $(-1.765)$ & $(1.753)$ & $(-2.900)$ & $(-1.869)$ & $(-0.729)$ \\
& & & & & & \\
OMT & $-50.905^{* *}$ & -24.485 & 7.990 & $-72.709^{* * *}$ & $-48.643^{* *}$ & 0.703 \\
9-06-2012 & $(-2.349)$ & $(-1.097)$ & $(0.965)$ & $(-3.751)$ & $(-2.356)$ & $(0.177)$
\end{tabular}




\section{Table 3: Impact of ECB interventions on banks}

This table reports the percentage change in average bank CDS spread and market capitalization following following LTRO1 (12-21-2011), LTRO2 (02-29-2012), and OMT (07-26-2012). Panel A: percentage change in average 5-year bank CDS spread. Panel B: percentage change in average 3-year bank CDS spread. Panel C: percentage change in average bank equity prices. Note that "OMT" corresponds to the date of M. Draghi' speech. IS stands for Italy and Spain. GIIPS excludes Greece. Sample: public banks that participated in all EBA stress tests (excludes Dexia, Greek and Cypriot banks).

\begin{tabular}{l|rrr}
\multicolumn{4}{c}{ Panel A: Change in average bank 5-yr CDS (\%) } \\
\hline & GIIPS (IS) & Euro nonGIIPS & nonEuro \\
\hline LTRO1 - LTRO2 & $-20(-30)$ & -24 & -19 \\
LTRO2 - OMT & $25(47)$ & 23 & 18 \\
post OMT & $-27(-39)$ & -45 & -55 \\
& & &
\end{tabular}

Panel B: Change in average bank 3-yr CDS (\%)

\begin{tabular}{l|rrr}
\hline & GIIPS (IS) & Euro nonGIIPS & nonEuro \\
\hline LTRO1 - LTRO2 & $-31(-42)$ & -33 & -20 \\
LTRO2 - OMT & $22(55)$ & 25 & 14 \\
post OMT & $-39(-54)$ & -69 & -59
\end{tabular}

Panel C: Change in average bank equity prices (\%)

\begin{tabular}{l|rrr}
\hline & GIIPS (IS) & Euro nonGIIPS & nonEuro \\
\hline LTRO1 - LTRO2 & $15(8)$ & 30 & 25 \\
LTRO2 - OMT & $-60(-62)$ & -36 & -11 \\
post OMT & $36(29)$ & 41 & 7
\end{tabular}




\section{Table 4: Sovereign bond holdings of banks}

This table reports the change (in EUR bn) in overall sovereign bond holdings of banks in Panel A, the change in sovereign bond holding of short maturity (between 1 and 3 years) in Panel B, and the change in sovereign bond holding of long maturity (above 3 years) in Panel C. GIIPS excludes Greece. Sample: public banks that participated in all EBA stress tests (excludes Dexia, Greek and Cypriot banks).

Panel A: Change in sovereign bond holdings (EUR bn)

\begin{tabular}{l|rrr|rr}
\hline & \multicolumn{3}{|c|}{ Change in home exposure } & \multicolumn{2}{c}{ Change in GIIPS exposure } \\
& GIIPS & Italy & Spain & Euro nonGIIPS & nonEuro \\
\hline Dec'10-Dec'11 & -17 & -16 & 1 & -59 & -18 \\
Dec'11-June'12 (post LTRO) & 55 & 36 & 13 & -9 & -6 \\
June-Dec'12 (post OMT) & 12 & 14 & -3 & 4 & -1 \\
Dec'12-Dec'13 & -8 & 11 & -18 & 13 & -1
\end{tabular}

Panel B: Change in sovereign bond holdings (between 1 and 3-yr maturity)

\begin{tabular}{l|rr|rr|rr}
\hline & \multicolumn{2}{|c|}{ change in GIIPS exp } & \multicolumn{2}{c|}{ change in Italian exp } & \multicolumn{2}{c}{ change in Spanish exp } \\
& GIIPS & non-GIIPS & Italian & non-Italian & Spanish & non-Spanish \\
\hline Dec'10-Dec'11 & -35 & -30 & -22 & -18 & -10 & -7 \\
Dec'11-June'12 (post LTRO) & 37 & -1 & 29 & 4 & 6 & -1 \\
June-Dec'12 (post OMT) & 17 & 1 & 8 & -1 & -7 & 2 \\
Dec'12-Dec'13 & -1 & 8 & 15 & 4 & -11 & 3
\end{tabular}

Panel C: Change in sovereign bond holdings (above 3-yr maturity)

\begin{tabular}{l|rr|rr|rr}
\hline & \multicolumn{2}{|c|}{ change in GIIPS exp } & \multicolumn{2}{c|}{ change in Italian exp } & \multicolumn{2}{c}{ change in Spanish exp } \\
& GIIPS & non-GIIPS & Italian & non-Italian & Spanish & non-Spanish \\
\hline Dec'10-Dec'11 & 16 & -29 & 6 & -21 & 11 & -5 \\
Dec'11-June'12 (post LTRO) & 15 & -8 & 8 & -1 & 7 & 0 \\
June-Dec'12 (post OMT) & 22 & 3 & 6 & 6 & 4 & -2 \\
Dec'12-Dec'13 & -14 & 5 & -4 & 5 & -7 & 1
\end{tabular}




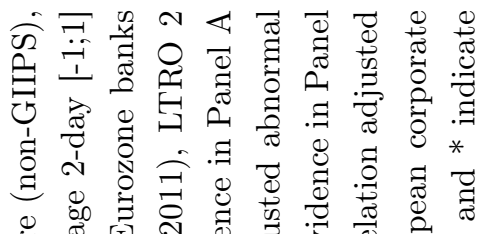

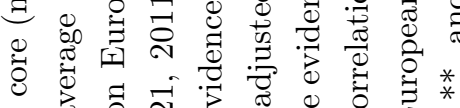

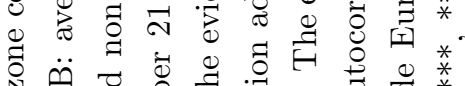

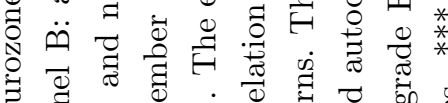

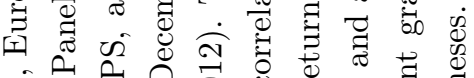

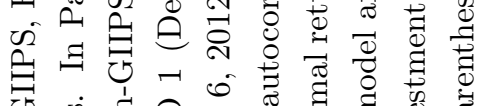

ซ)

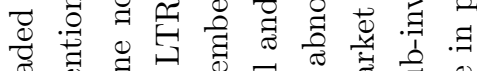

ॠ

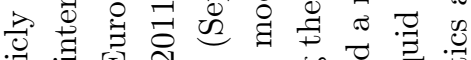

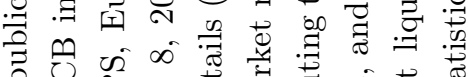

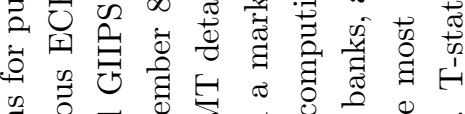

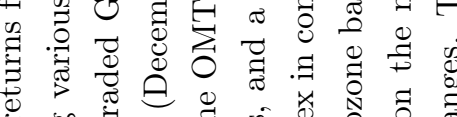

过

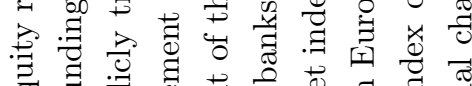

ఫ্

ฮี పี

荡

స్

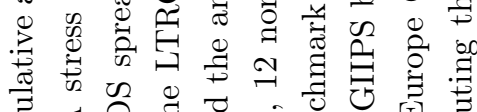

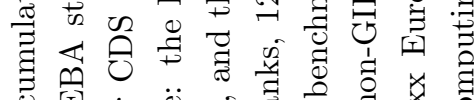

ठิ

F

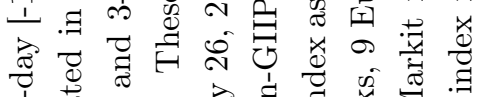

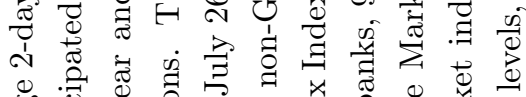

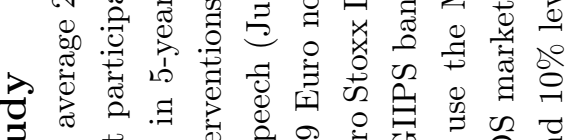

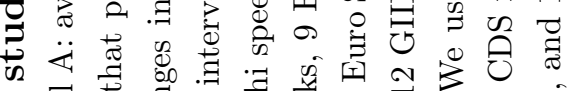

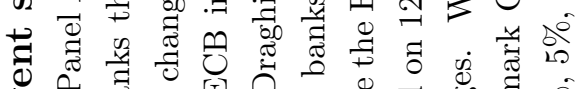
D. עै ติ

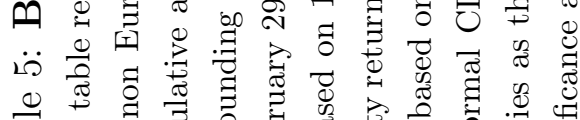

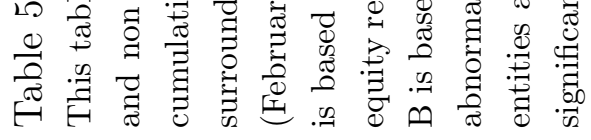

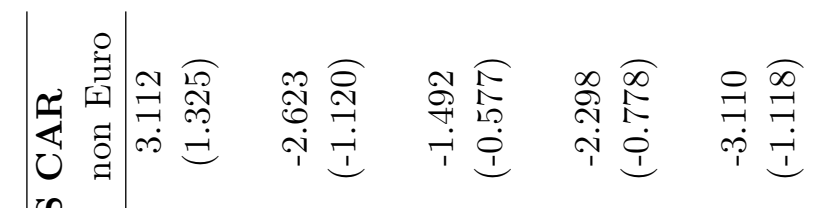

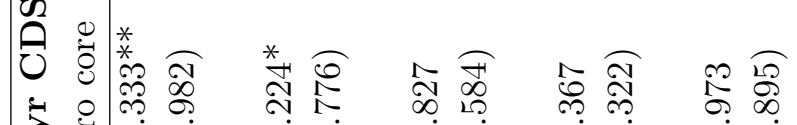

की

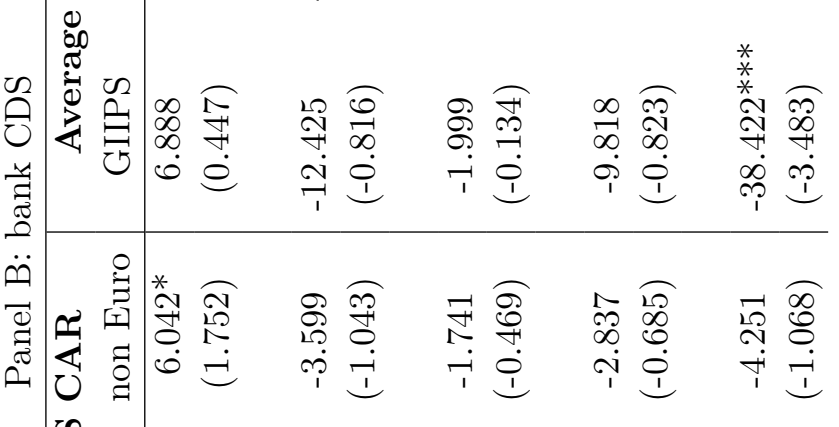

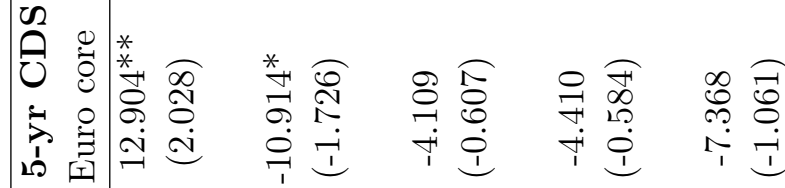

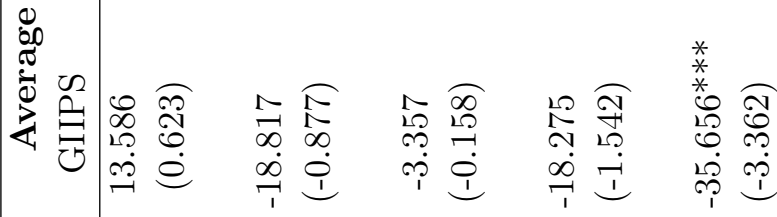

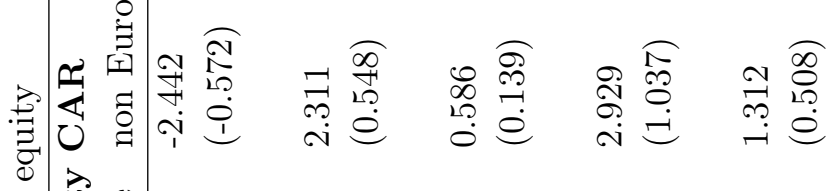

崖

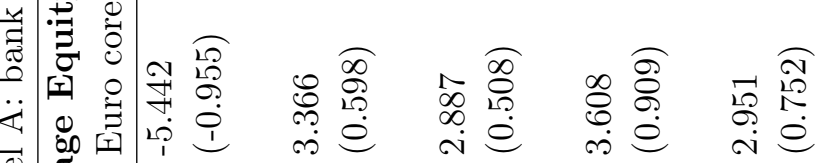

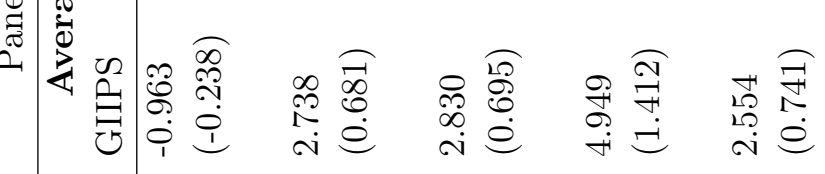

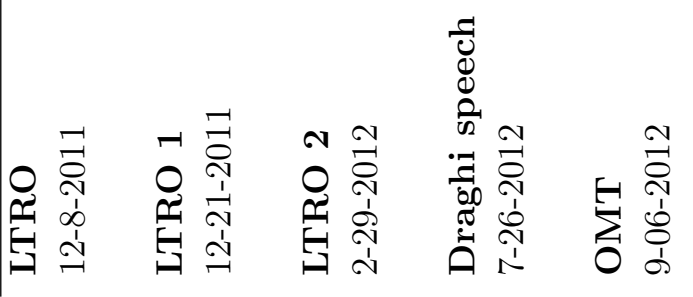


Table 6: Regression analysis of determinants of CDS CARs surrounding various ECB interventions

This table presents estimates from a linear regression analysis of the determinants of 2-day [-1;1] 5-year CDS CARs surrounding the different ECB interventions. Independent variables are each banks' GIIPS and Eurozone non-GIIPS sovereign bond holdings scaled by total assets. Tier1 is Tier 1 capital divided by riskweighted assets; RWA/TA is risk-weighted assets divided by total assets. Bank characteristics and sovereign bond holdings are from the period prior to the intervention. T-statistics based on heteroskedasticity-robust standard errors are in parentheses. ***, **, and * indicate significance at the 1\%, 5\%, and $10 \%$ levels, respectively. $R^{2}$ is the adjusted $R^{2}$.

5-yr CDS CARs

\begin{tabular}{l|ccccc}
\hline & LTRO & LTRO 1 & LTRO 2 & Draghi speech & OMT \\
\hline GIIPS/Assets & 100.85 & -148.36 & $-105.30^{*}$ & $-365.65^{* * *}$ & $-674.06^{* *}$ \\
& $(1.23)$ & $(-1.57)$ & $(-1.73)$ & $(-3.57)$ & $(-2.30)$ \\
Euro nonGIIPS/Assets & -75.15 & 33.73 & -64.89 & -127.64 & -160.89 \\
& $(-1.09)$ & $(0.40)$ & $(-0.70)$ & $(-1.17)$ & $(-0.72)$ \\
Log-Assets & & & & & \\
& 1.18 & 2.35 & -3.78 & -7.04 & -3.26 \\
Tier 1 & $(0.51)$ & $(0.78)$ & $(-1.31)$ & $(-2.65)$ & $(-0.79)$ \\
& & & & & \\
RWA/Assets & $-962.19^{* * *}$ & 578.55 & 34.71 & -109.12 & 24.42 \\
& $(-4.48)$ & $(1.49)$ & $(0.11)$ & $(-0.21)$ & $(0.03)$ \\
Constant & $75.43^{* * *}$ & $-65.27^{*}$ & -9.49 & 17.81 & 17.39 \\
& $(2.96)$ & $(-1.85)$ & $(-0.33)$ & $(0.39)$ & $(0.27)$ \\
& & & & & \\
$N$ & 17.38 & -24.98 & 27.08 & 44.92 & 12.75 \\
$R^{2}$ & $(0.96)$ & $(-1.04)$ & $(1.09)$ & $(1.98)$ & $(0.31)$ \\
& & & & & 27 \\
\hline
\end{tabular}


Table 7: U.S. MMF funding flows at GIIPS, Eurozone non-GIIPS, and nonEurozone banks

This table presents estimates from a linear regression analysis of the determinants of U.S. MMF flows at a bank surrounding the different ECB interventions. The regression is a pooled OLS regression where the dependent variable is the percentage change in principal amount at date t. The regression is augmented by deterministic interaction terms to account for changing parameters before the sovereign debt crisis ("precrisis"), during the crisis ("crisis"), after LTRO 2 ("post LTRO"), and after the OMT announcement ("post OMT"). Pre crisis period: Nov 2010 - May 2011; Crisis period: June 2011 - Dec 2011; Post LTRO period: Jan 2012 - Sept 2012; Post OMT period: Oct 2012 - Aug 2014. AR: autoregressive parameter. ***, **, and $*$ indicate significance (based on panel robust standard errors) at the $1 \%, 5 \%$, and $10 \%$ levels, respectively.

\begin{tabular}{|c|c|c|c|c|}
\hline & \multicolumn{2}{|c|}{ Unsecured } & \multicolumn{2}{|c|}{ Secured } \\
\hline & avg. flow & marg. effect & avg. flow & marg. effect \\
\hline GIIPS, pre-crisis & $-0.102^{* * *}$ & $-0.142^{* * *}$ & & \\
\hline GIIPS, crisis & $-0.453^{* * *}$ & $-0.426 * * *$ & & \\
\hline GIIPS, post LTRO & $-0.213^{* * *}$ & $-0.196^{* * *}$ & & \\
\hline GIIPS, post OMT & $0.272^{* * *}$ & $0.258^{* * *}$ & & \\
\hline Euro nonGIIPS, pre-crisis & -0.016 & -0.057 & 0.005 & -0.017 \\
\hline Euro nonGIIPS, crisis & $-0.267 * * *$ & $-0.240 * * *$ & -0.023 & -0.049 \\
\hline Euro nonGIIPS, post LTRO & 0.061 & 0.078 & $0.009^{* *}$ & $0.017^{* *}$ \\
\hline Euro nonGIIPS, post OMT & 0.007 & -0.007 & -0.008 & $0.034^{*}$ \\
\hline non-Euro, pre-crisis & $0.041^{* * *}$ & & 0.021 & \\
\hline non-Euro, crisis & -0.027 & & $0.026^{* *}$ & \\
\hline non-Euro, post LTRO & -0.017 & & -0.008 & \\
\hline non-Euro, post OMT & 0.014 & & $-0.042^{* * *}$ & \\
\hline $\mathrm{AR}$ & $0.038^{* * *}$ & & $0.389 * * *$ & \\
\hline $\mathrm{R}^{2}(\%)$ & 10.046 & & 16.379 & \\
\hline Adj. $\mathrm{R}^{2}(\%)$ & 9.394 & & 15.098 & \\
\hline Sample & $\begin{array}{l}1667 \text { observ } \\
56 \text { banks }\end{array}$ & tions & $\begin{array}{l}531 \text { obser } \\
13 \text { banks }\end{array}$ & ons \\
\hline
\end{tabular}




\section{Table 8: MMF flows and other sources of funding}

Panel A presents estimates from a time-series regressions that explain aggregate flows of debt securities of residual maturity of one year at EU-28 banks (Source: ESRB). Banks' short-term debt includes commercial papers, certificates of deposits and short-term notes with a maximum maturity of 12 months. Panel B presents estimates from cross-sectional regressions that explain demand for public funding through the 3-year Long-Term Refinancing Operations (LTRO). Probit: the dependent variable is a dummy variable equal to one if bank received LTRO funding (LTRO 1 and 2 combined). OLS: the dependent variable is the logarithm of LTRO funding received, if LTRO amount is positive. GIIPS(2011): GIIPS gross direct exposure (in hundredth of percentage of total assets) as of end September 2011, CDS(2011): CDS price as of end November 2011. Standard errors in parentheses (Newey-West standard errors in Panel A, White standard errors for OLS regressions in Panel B). ***, **, and * indicate significance at the 1\%, $5 \%$, and 10\% levels, respectively.

Panel A: U.S. MMF flows and short-term debt securities flows

\begin{tabular}{|c|c|c|c|c|}
\hline & \multicolumn{4}{|c|}{ 1-year debt flow at EU-28 banks } \\
\hline MMF unsecured flow (t-1) & $\begin{array}{c}0.081^{*} \\
(0.046)\end{array}$ & & & $\begin{array}{c}0.107^{* *} \\
(0.050)\end{array}$ \\
\hline MMF secured flow (t-1) & & $\begin{array}{c}0.039 \\
(0.090)\end{array}$ & & $\begin{array}{c}0.089 \\
(0.091)\end{array}$ \\
\hline 2-year debt flow (t-1) & & & $\begin{array}{l}-0.835^{* *} \\
(0.321)\end{array}$ & $\begin{array}{l}-0.824^{* *} \\
(0.315)\end{array}$ \\
\hline $\mathrm{AR}$ & $\begin{array}{c}0.002 \\
(0.102)\end{array}$ & $\begin{array}{c}0.030 \\
(0.131)\end{array}$ & $\begin{array}{c}0.356^{*} \\
(0.209)\end{array}$ & $\begin{array}{c}0.292 \\
(0.202)\end{array}$ \\
\hline Constant & $\begin{array}{l}-0.264 \\
(0.321)\end{array}$ & $\begin{array}{l}-0.285 \\
(0.344)\end{array}$ & $\begin{array}{l}-0.517 \\
(0.329)\end{array}$ & $\begin{array}{l}-0.365 \\
(0.293)\end{array}$ \\
\hline $\begin{array}{l}\mathrm{R}^{2}(\%) \\
\text { Adj. } \mathrm{R}^{2}(\%) \\
\text { Estimation sample }\end{array}$ & $\begin{array}{l}4.133 \\
-0.544 \\
2011(2)\end{array}$ & $\begin{array}{c}0.572 \\
-4.277 \\
2014(9)\end{array}$ & $\begin{array}{r}12.411 \\
8.138\end{array}$ & $\begin{array}{l}16.549 \\
10.290\end{array}$ \\
\hline
\end{tabular}




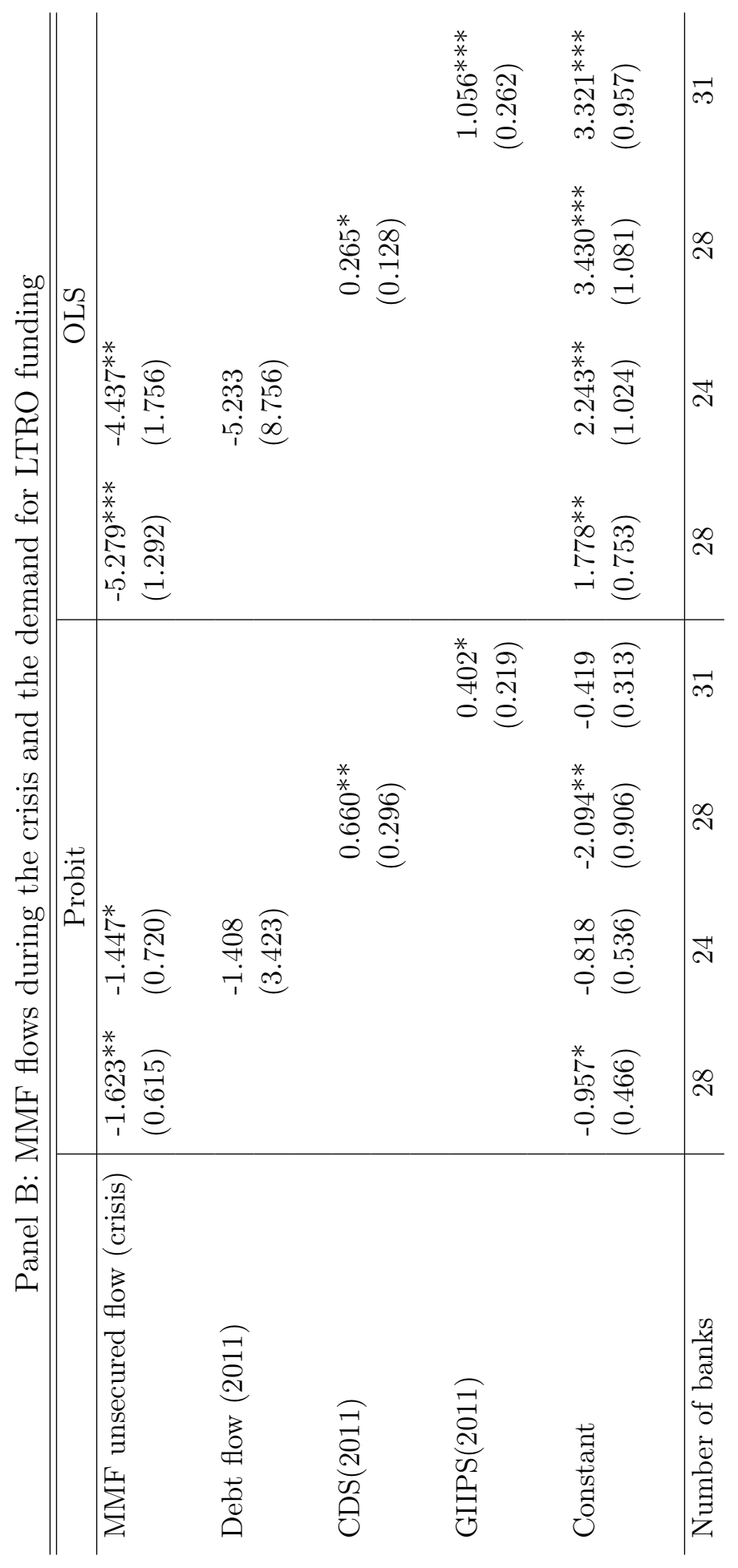




\section{Table 9: Impact of ECB interventions on U.S. MMF funding flows}

This table reports the change in U.S. money market funds investments (in USD bn) at European banks following LTRO1 (12-21-2011), LTRO2 (02-29-2012), and OMT (07-26-2012). Percentage change in parentheses. Note that "OMT" corresponds to the date of M. Draghi' speech. Banco Santander is the only GIIPS bank that recover access to U.S. MMFs (all other GIIPS banks lose access in 2011). Sample: European banks with access to U.S. MMFs.

Panel A: Change in MMF investments in \$bn (\%) - unsecured

\begin{tabular}{l|rrr}
\hline & Banco Santander & Euro nonGIIPS & nonEuro \\
\hline LTRO1 - LTRO2 & $-0.49(-99 \%)$ & $14(19 \%)$ & $-27(-16 \%)$ \\
LTRO2 - OMT & $0.10(2757 \%)$ & $-19(-21 \%)$ & $-28(-19 \%)$ \\
post OMT & $0.93(-)$ & $61(89 \%)$ & $11(8 \%)$
\end{tabular}

Panel B: Change in MMF investments in \$bn (\%) - secured

\begin{tabular}{l|rr}
\hline & Euro nonGIIPS & nonEuro \\
\hline LTRO1 - LTRO2 & $56(44 \%)$ & $23(13 \%)$ \\
LTRO2 - OMT & $-46(-25 \%)$ & $-27(-14 \%)$ \\
post OMT & $-47(-27 \%)$ & $-87(-45 \%)$
\end{tabular}

Panel C: Change in MMF investments in \$bn (\%) - secured, seasonality adjusted

\begin{tabular}{l|rr}
\hline & Euro nonGIIPS & nonEuro \\
\hline LTRO1 - LTRO2 & $1(0 \%)$ & $9(6 \%)$ \\
LTRO2 - OMT & $-7(-4 \%)$ & $3(2 \%)$ \\
post OMT & $-72(-40 \%)$ & $-10(-6 \%)$
\end{tabular}




\section{Table 10: U.S. MMF funding flows at European banks according to risk}

This table presents estimates from a linear regression analysis of the determinants of U.S. MMF flows at a bank surrounding the different ECB interventions. The regression is a pooled OLS regression where the dependent variable is the percentage change in principal amount at date t. The regression is augmented by deterministic interaction terms to account for changing parameters before the sovereign debt crisis ("precrisis"), during the crisis ("crisis"), after LTRO 2 ("post LTRO"), and after the OMT announcement ("post OMT"). Pre crisis period: Nov 2010 - May 2011; Crisis period: June 2011 - Dec 2011; Post LTRO period: Jan 2012 - Sept 2012; Post OMT period: Oct 2012 - Aug 2014. AR: autoregressive parameter; GIIPSexp: GIIPS gross direct exposure (percentage of total assets) updated before each period starts; CDS: CDS price updated before each period starts. $* * *, * *$, and * indicate significance (based on panel robust standard errors) at the $1 \%, 5 \%$, and $10 \%$ levels, respectively.

\begin{tabular}{|c|c|c|c|c|c|c|}
\hline & \multicolumn{3}{|c|}{ Unsecured } & \multicolumn{3}{|c|}{ Secured } \\
\hline CDS, pre-crisis & $-0.065^{* * *}$ & & $-0.071^{* * *}$ & -0.019 & & 0.002 \\
\hline CDS, crisis & $-0.168 * * *$ & & $-0.101^{* *}$ & -0.070 & & 0.009 \\
\hline CDS, post LTRO & -0.024 & & -0.020 & $0.009^{*}$ & & 0.007 \\
\hline CDS, post OMT & $0.022^{* *}$ & & 0.014 & $0.019 * * *$ & & $0.020^{* * *}$ \\
\hline GIIPSexp, pre-crisis & & -0.346 & 0.522 & & $-9.915^{* * *}$ & -9.883 \\
\hline GIIPSexp, crisis & & $-4.903^{* * *}$ & $-3.267 * *$ & & $-17.432^{*}$ & $-17.694^{* *}$ \\
\hline GIIPSexp, post LTRO & & -2.047 & -1.508 & & $3.116^{* * *}$ & $2.461^{* *}$ \\
\hline GIIPSexp, post OMT & & $1.631^{* * *}$ & 1.044 & & $2.601^{*}$ & 0.842 \\
\hline pre-crisis & $0.041^{* *}$ & -0.032 & 0.040 & 0.020 & $0.094^{*}$ & $0.092^{* *}$ \\
\hline crisis & $0.101^{* * *}$ & $-0.050 * *$ & 0.055 & 0.070 & $0.150^{* *}$ & 0.141 \\
\hline post LTRO & 0.054 & 0.010 & 0.052 & $-0.019 *$ & -0.012 & $-0.025^{* *}$ \\
\hline post OMT & $-0.025 * * *$ & 0.003 & -0.016 & $-0.035^{* * *}$ & -0.012 & $-0.042^{* *}$ \\
\hline $\mathrm{AR}$ & $0.534^{* * *}$ & $0.543^{* * *}$ & $0.522^{* * *}$ & $0.451^{* * *}$ & $0.345^{* * *}$ & $0.339^{* * *}$ \\
\hline $\mathrm{R}^{2}(\%)$ & 43.418 & 42.971 & 44.256 & 19.649 & 28.762 & 28.985 \\
\hline Adj. $\mathrm{R}^{2}(\%)$ & 42.877 & 42.426 & 43.453 & 17.555 & 26.905 & 26.172 \\
\hline Sample & $\begin{array}{l}846 \text { observ } \\
29 \text { banks }\end{array}$ & tions & & $\begin{array}{l}316 \text { obser } \\
9 \text { banks }\end{array}$ & ions & \\
\hline
\end{tabular}




\section{Table 11: Losing access to U.S. MMFs after ECB interventions}

Panel A: the regression is a pooled OLS regression where the dependent variable is the change in the number of securities invested at a bank at date t. Panel B: the regression is a pooled Probit regression where the dependent variable is the probability of losing access to MMFs when the bank had access at time t-1 ( $\mathrm{P}$ (Losing access to all funds) ), or the probability of losing access to one fund when the bank had access to the fund at time t-1 (P(Losing access to one fund)). GIIPSexp: GIIPS gross direct exposure (percentage of total assets) updated before each period starts. AR: autoregressive parameter. ***, **, and * indicate significance (based on panel robust standard errors for OLS regressions) at the 1\%,5\%, and $10 \%$ levels, respectively. $\mathrm{R}^{2}$ is adjusted $\mathrm{R}^{2}$ for OLS regressions, and Pseudo $\mathrm{R}^{2}$ of McFadden for Probit regressions.

Panel A: Change in the number of MMF securities invested at a bank

\begin{tabular}{|c|c|c|c|c|c|}
\hline & Unsecured & Secured & & Unsecured & Secured \\
\hline GIIPS, pre-crisis & $-1.494^{*}$ & & GIIPSexp, pre-crisis & $-122.257^{* * *}$ & 6.080 \\
\hline GIIPS, crisis & $-3.573^{* * *}$ & & GIIPSexp, crisis & 4.823 & 3.404 \\
\hline GIIPS, post LTRO & -0.163 & & GIIPSexp, post LTRO & 1.308 & 3.225 \\
\hline GIIPS, post OMT & 0.341 & & GIIPSexp, post OMT & $41.227^{* *}$ & 9.589 \\
\hline Euro nonGIIPS, pre-crisis & 0.573 & -0.136 & pre-crisis & $4.692 * * *$ & 0.440 \\
\hline Euro nonGIIPS, crisis & $-7.295^{* * *}$ & $-0.782^{*}$ & crisis & $-7.450^{* * *}$ & -1.045 \\
\hline Euro nonGIIPS, post LTRO & $1.034^{* *}$ & 0.376 & post LTRO & 0.315 & 0.392 \\
\hline Euro nonGIIPS, post OMT & $0.731^{* *}$ & $0.306^{*}$ & post OMT & 0.446 & 0.186 \\
\hline non-Euro, pre-crisis & $4.572^{* * *}$ & 1.135 & & & \\
\hline non-Euro, crisis & -1.052 & 1.591 & & & \\
\hline non-Euro, post LTRO & -1.395 & 0.108 & & & \\
\hline non-Euro, post OMT & 0.269 & $-0.929 * *$ & & & \\
\hline $\mathrm{AR}$ & $0.118^{* *}$ & $-0.324^{* * *}$ & $\mathrm{AR}$ & $0.159^{* * *}$ & $-0.339^{* * *}$ \\
\hline Adj. $R^{2}(\%)$ & 4.68 & 10.84 & Adj. $R^{2}(\%)$ & 6.37 & 11.41 \\
\hline Observations & 2,651 & 2,651 & Observations & 982 & 982 \\
\hline Banks & 61 & 61 & Banks & 29 & 29 \\
\hline
\end{tabular}


Panel B: Probit analysis for the probability of losing access to MMF unsecured funding

\begin{tabular}{|c|c|c|c|c|c|}
\hline & \multicolumn{2}{|c|}{$\mathrm{P}$ (losing access to $)$} & & \multicolumn{2}{|c|}{$\mathrm{P}($ losing access to $)$} \\
\hline & all funds & one fund & & all funds & one fund \\
\hline GIIPS, pre-crisis & $6.67^{* * *}$ & $23.30^{* * *}$ & GIIPSexp, pre-crisis & $-0.10\left(^{\star}\right)$ & $1.88^{* * *}\left({ }^{\star}\right)$ \\
\hline GIIPS, crisis & $15.00^{* * *}$ & $35.16^{* * *}$ & GIIPSexp, crisis & $1.03^{* *}\left({ }^{\star}\right)$ & $4.93^{* * *}\left({ }^{\star}\right)$ \\
\hline GIIPS, post LTRO & $14.29 * * *$ & 45.00 & GIIPSexp, post LTRO & $1.28^{* *}\left({ }^{\star}\right)$ & $6.20^{* * *}\left({ }^{\star}\right)$ \\
\hline GIIPS, post OMT & & $4.93^{* * *}$ & GIIPSexp, post OMT & $-0.15\left(^{\star}\right)$ & $0.50\left(^{\star}\right)$ \\
\hline Euro nonGIIPS, pre-crisis & $2.38 * * *$ & $9.66^{* * *}$ & pre-crisis & $1.70 * * *$ & $8.01^{* * *}$ \\
\hline Euro nonGIIPS, crisis & $8.19^{* * *}$ & $20.84^{* * *}$ & crisis & $3.14^{* * *}$ & $12.17^{* * *}$ \\
\hline Euro nonGIIPS, post LTRO & $6.17^{* * *}$ & $13.66^{* * *}$ & post LTRO & $0.90 * * *$ & $11.37^{* * *}$ \\
\hline Euro nonGIIPS, post OMT & $1.79 * * *$ & $11.21^{* * *}$ & post OMT & $0.27^{* * *}$ & $9.28^{* * *}$ \\
\hline non-Euro, pre-crisis & $1.10^{* * *}$ & $11.46^{* * *}$ & & & \\
\hline non-Euro, crisis & $1.89 * * *$ & $12.48^{* * *}$ & & & \\
\hline non-Euro, post LTRO & $0.74^{* * *}$ & $13.74^{* * *}$ & & & \\
\hline non-Euro, post OMT & $0.87^{* * *}$ & $9.30 * * *$ & & & \\
\hline Unconditional probability & 2.84 & 12.09 & Unconditional probability & 1.71 & 11.31 \\
\hline Pseudo $\mathrm{R}^{2}(\%)$ & 2.14 & 1.50 & Pseudo $\mathrm{R}^{2}(\%)$ & 15.64 & 2.02 \\
\hline Observations & 1,761 & 63,092 & Observations & 1,053 & 45,403 \\
\hline Banks & 63 & 63 & Banks & 34 & 30 \\
\hline
\end{tabular}

${ }^{\star}$ ) Change in probability corresponding to a $1 \%$ increase in GIIPS exposure for the median bank. 


\section{Figure 1: Sovereign risk}

This figure shows the average 5-year sovereign bond yields (Panel A) and average 5-year sovereign CDS prices (Panel B) of IIPS countries (Ireland, Italy, Portugal and Spain), Eurozone non-GIIPS countries, and non-Eurozone countries.

(a) Average sovereign yields

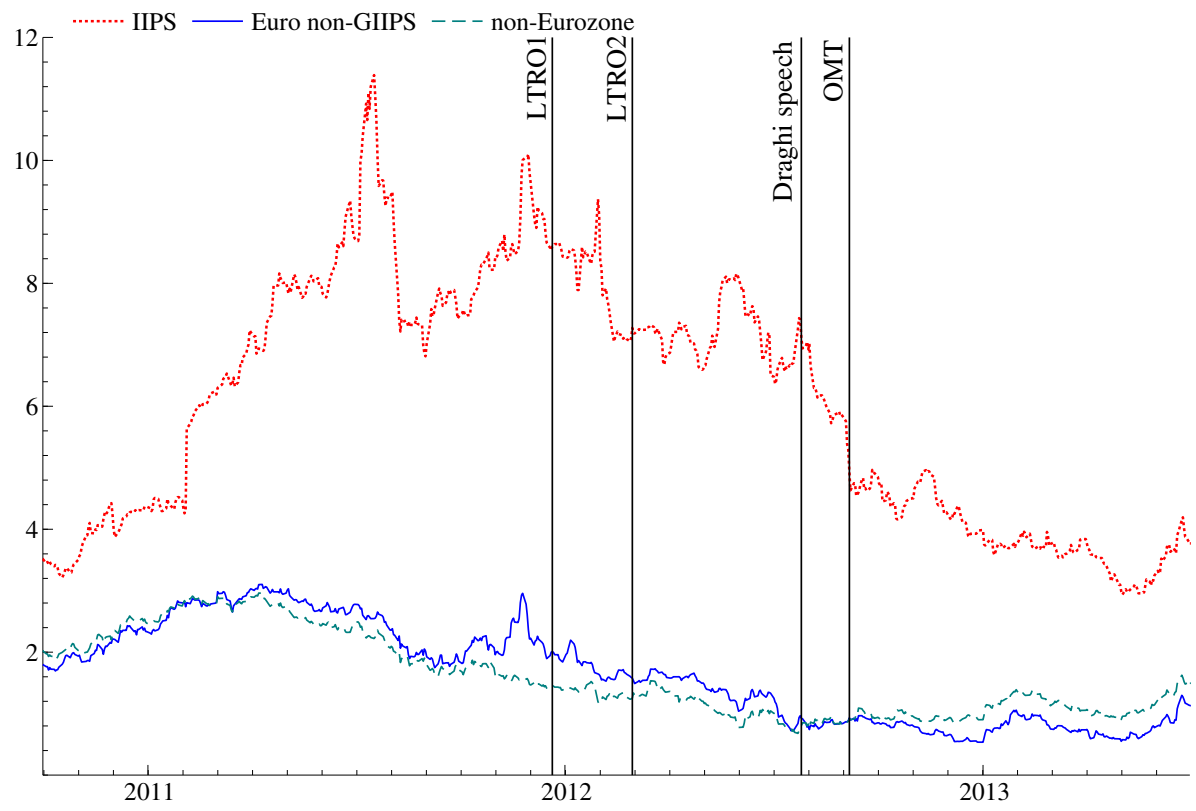

(b) Average sovereign CDS prices

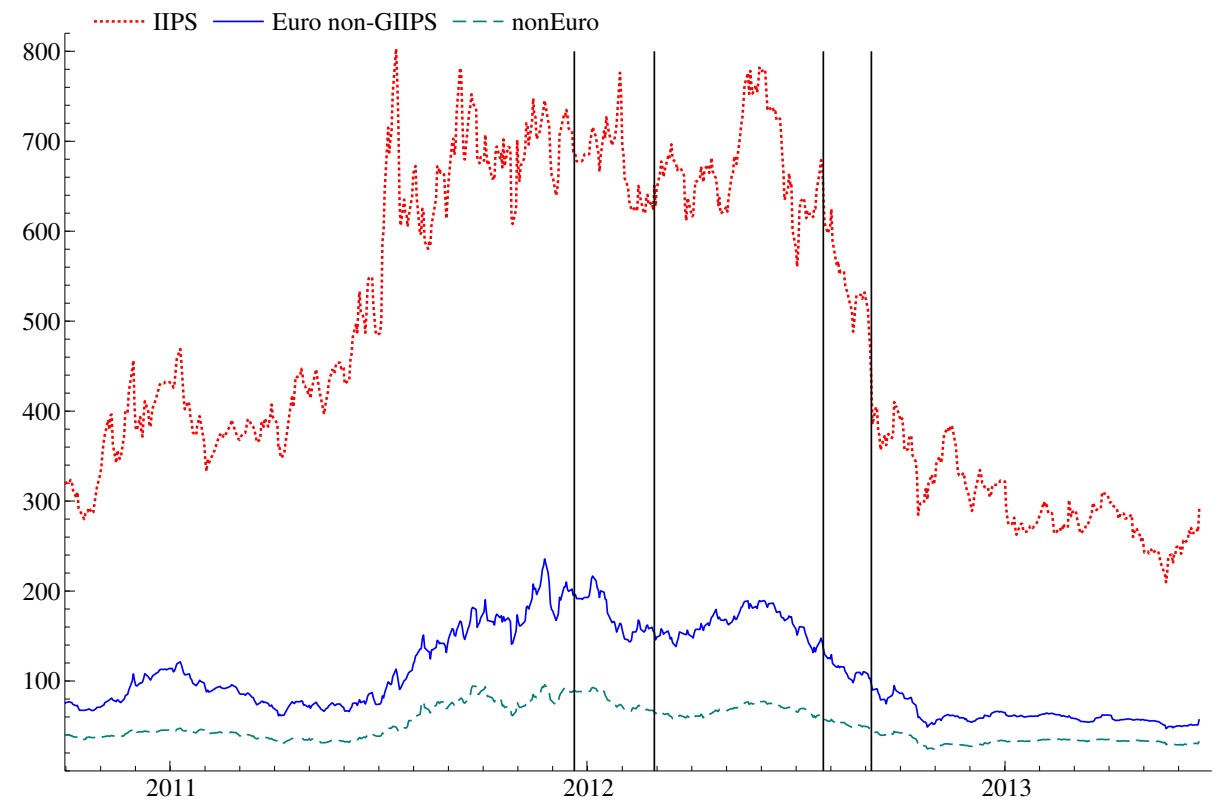


Figure 2: Solvency risk

This figure shows the average equity prices (Panel A) and average 5-year CDS prices (Panel B) of GIIPS banks (excluding Greek banks), Eurozone non-GIIPS banks (excluding Dexia), and non-Eurozone banks.

(a) Average bank equity prices

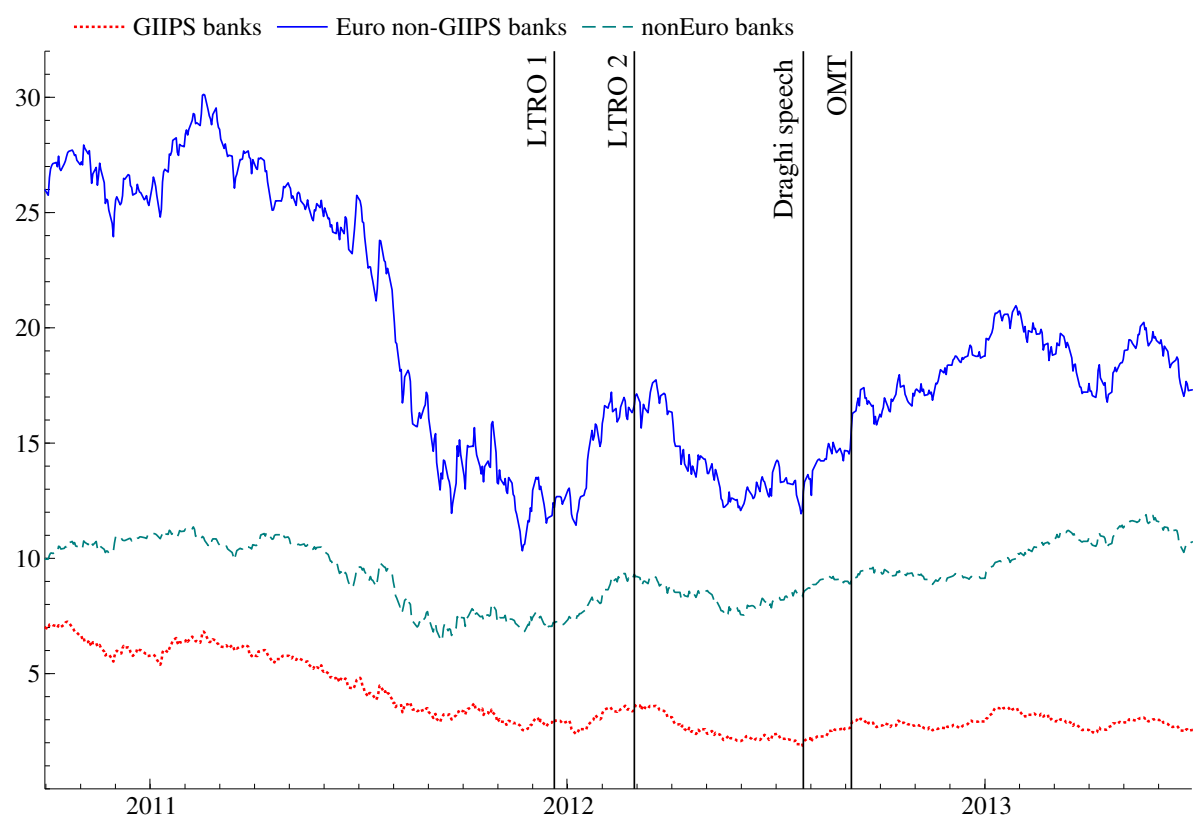

(b) Average bank CDS prices

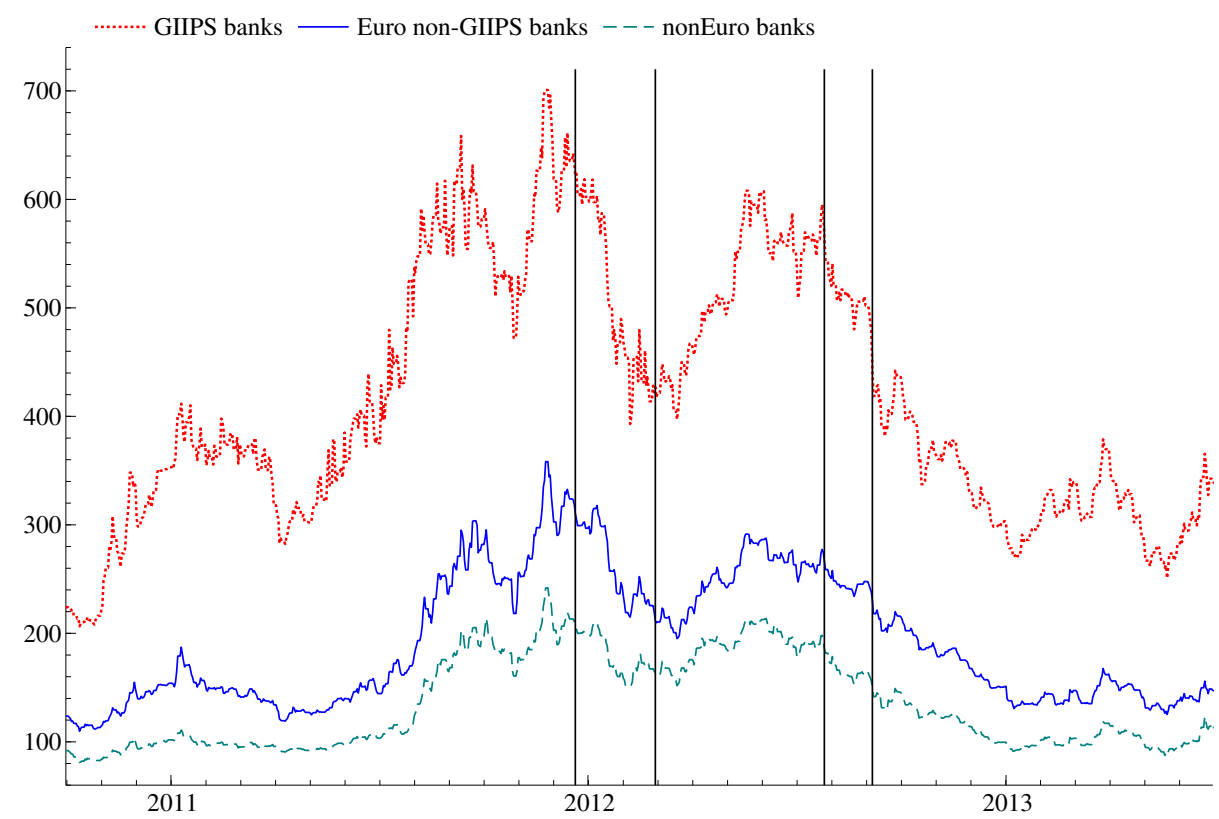


Figure 3: Money Market Funds investments at European banks

This figure shows the total principal amount (\$bn) of all securities invested by U.S. MMFs at European banks (Panel A), and the total principal amount (\$bn) of unsecured funding (CDs and financial CPs) vs. secured funding (repos) invested by U.S. MMFs at European banks (Panel B). Vertical bars indicate ECB interventions: SMP (08/2011), LTRO 1 (12/2011), LTRO 2 (03/2012), OMT (09/2012), ECB forward guidance $(07 / 2013)$, TLTRO $(06 / 2014)$.

(a) MMF investments (\$bn) - All securities

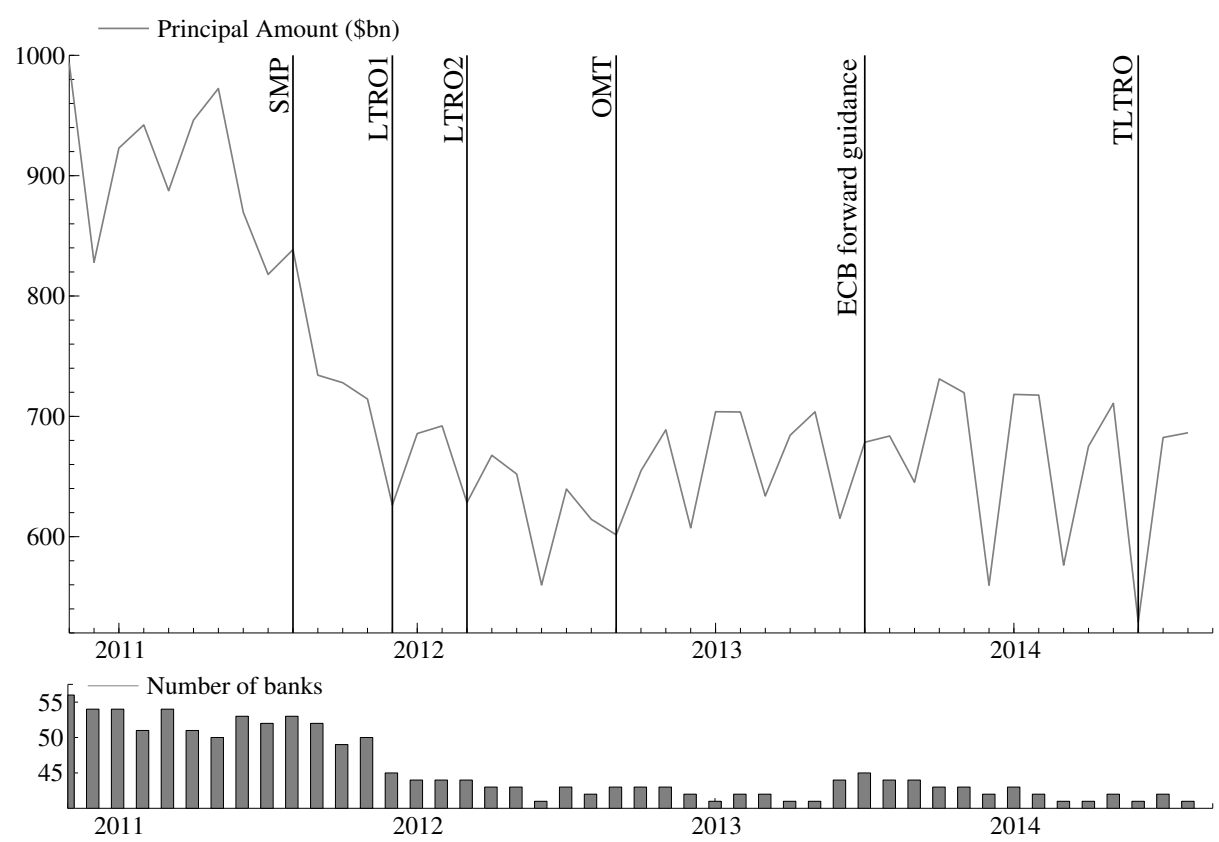

(b) MMF investments (\$bn) - Secured (repos) vs. unsecured funding

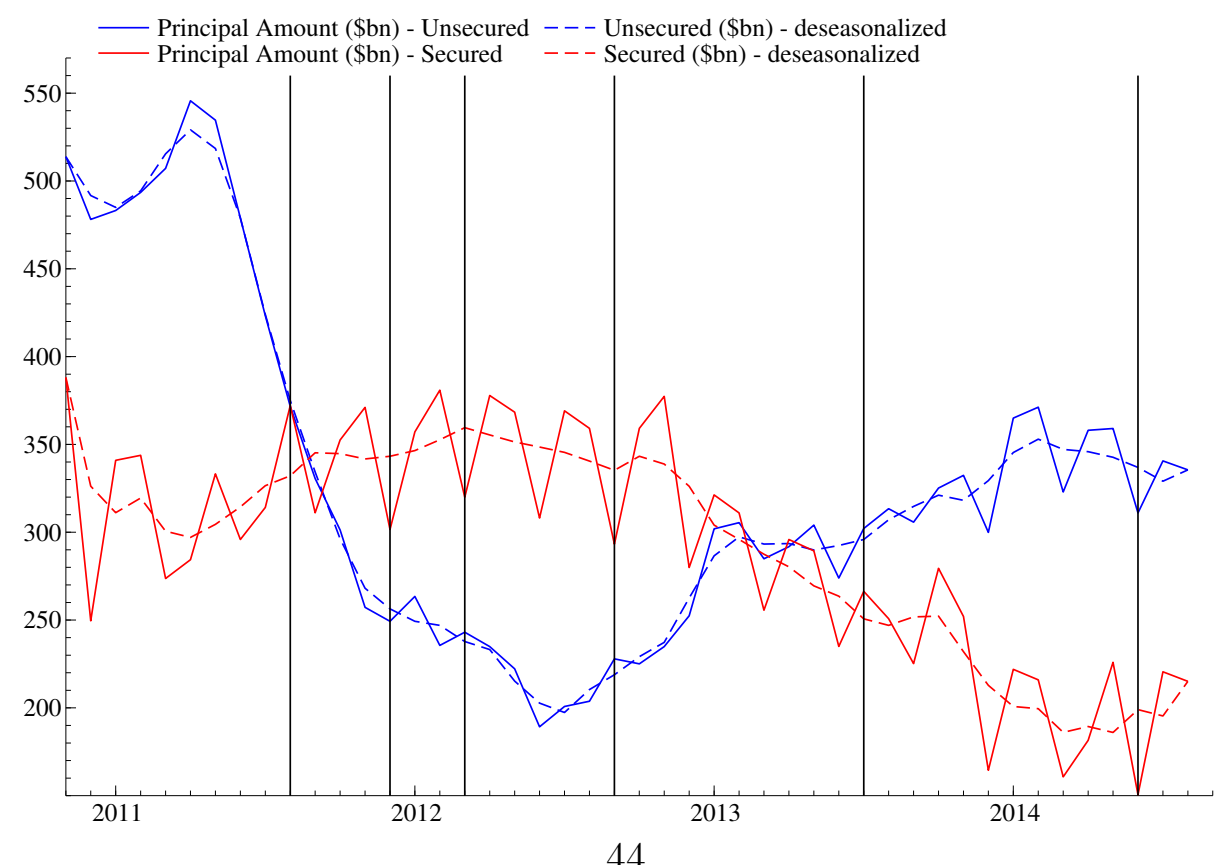


Figure 4: MMF unsecured investments at GIIPS, Eurozone non-GIIPS, and nonEurozone banks

This figure shows the principal amounts of unsecured funding (\$bn) invested at GIIPS, Eurozone non-GIIPS, and non-Eurozone banks. Vertical bars indicate ECB interventions: SMP (08/2011), LTRO $1(12 / 2011)$, LTRO 2 (03/2012), OMT (09/2012), ECB forward guidance (07/2013), TLTRO (06/2014).

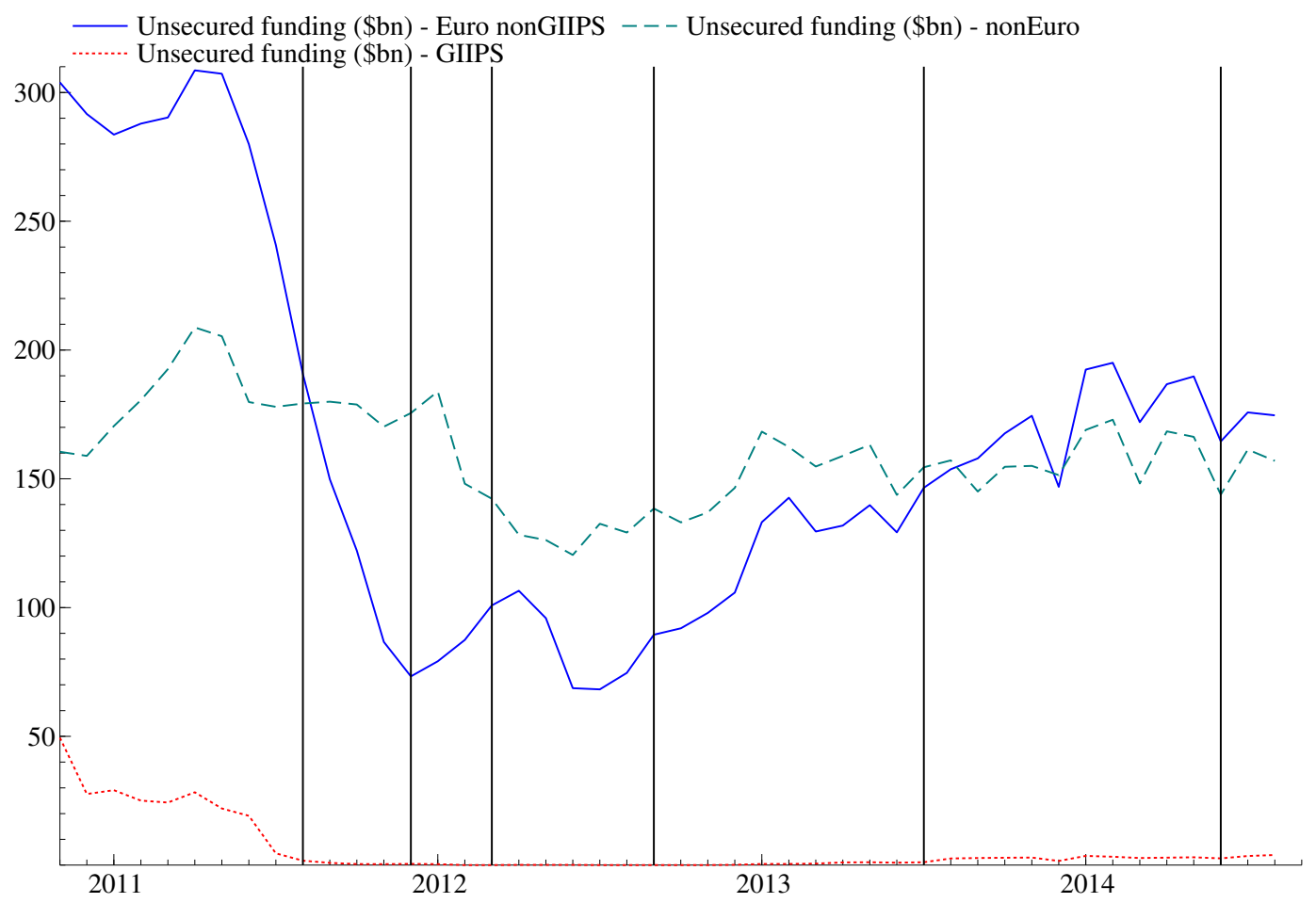




\section{Figure 5: The role of bank risk in MMF unsecured investments}

This figure shows the principal amount of unsecured funding (\$bn) invested at European banks (Panel A), and at Eurozone banks (Panel B) according to the CDS price of a bank in November 2010. "high (low) risk": principal amount at banks with 2010 CDS price higher (lower) than the median of CDS prices in November 2010. Vertical bars indicate ECB interventions: SMP (08/2011), LTRO 1 (12/2011), LTRO 2 (03/2012), OMT (09/2012), ECB forward guidance (07/2013), TLTRO (06/2014).

(a) European banks (including non-Eurozone)

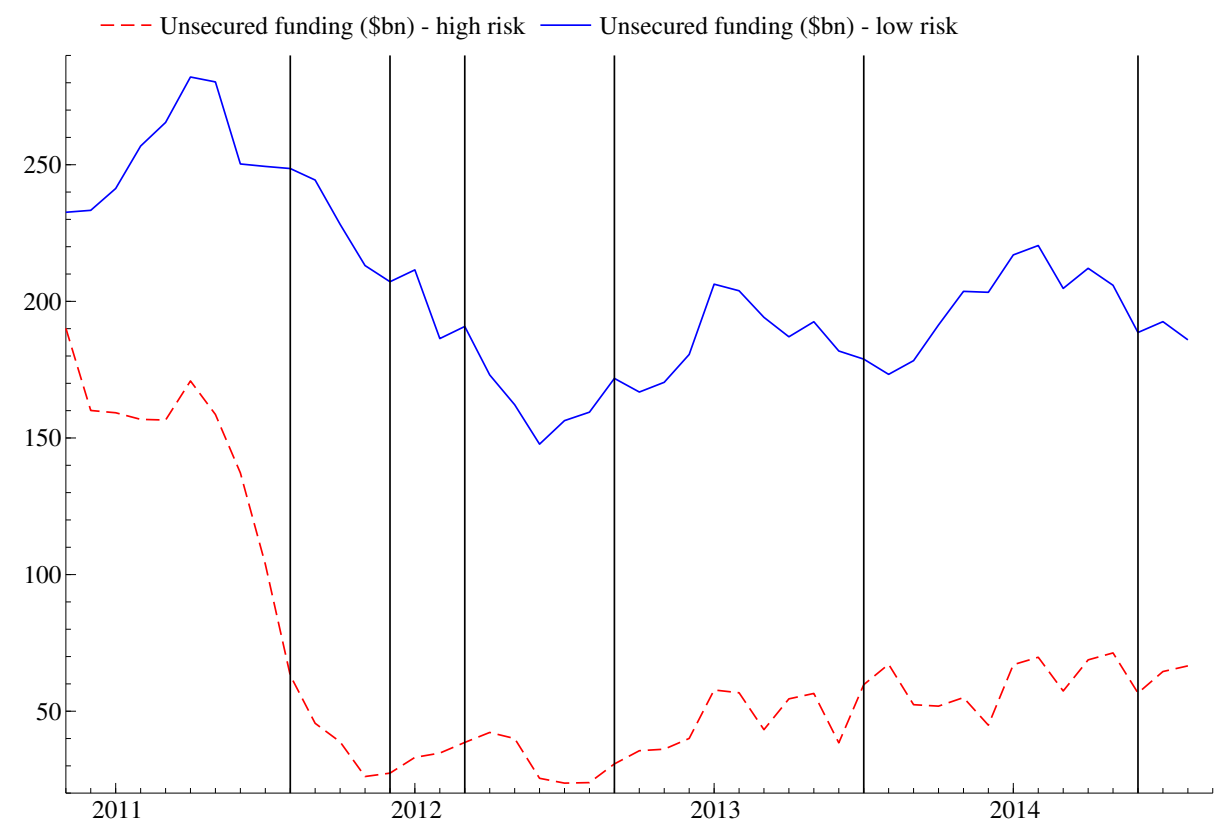

(b) Eurozone banks

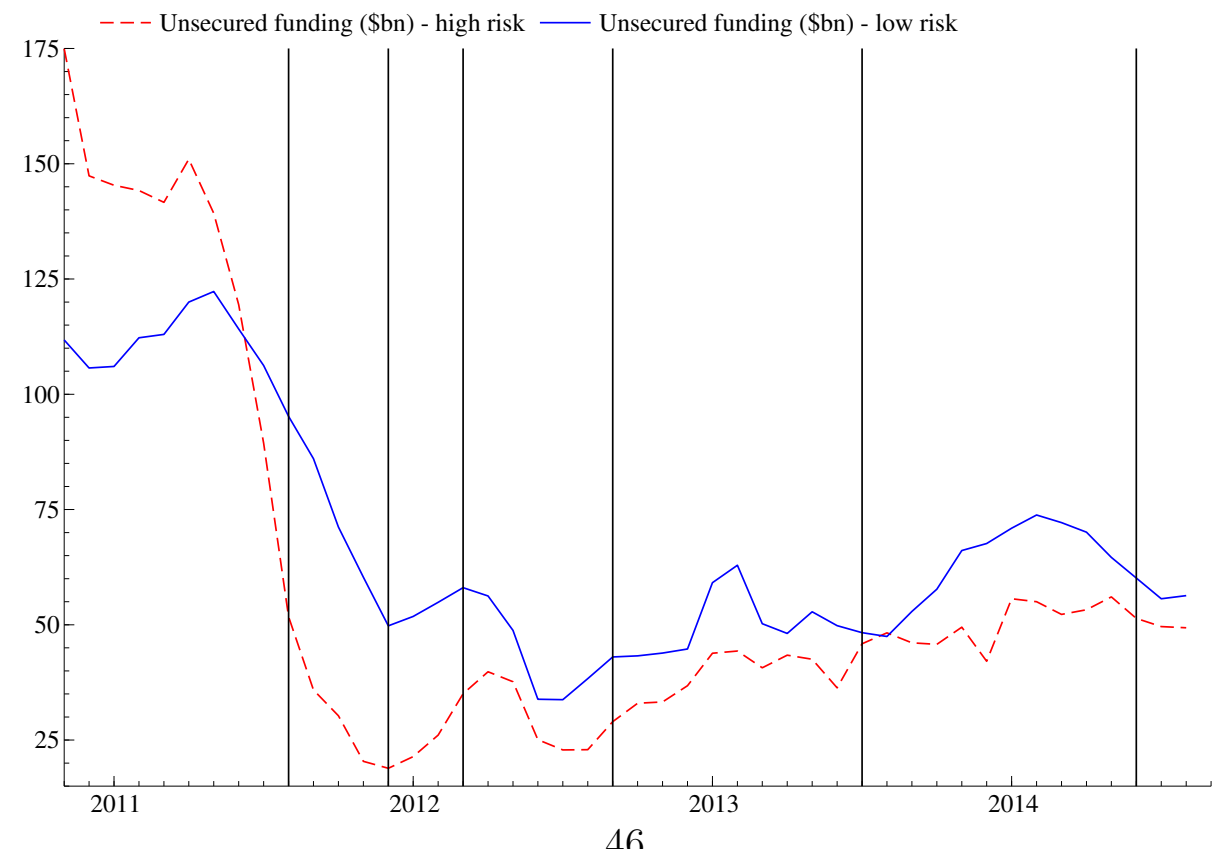


Figure 6: Private vs. public funding

The figure shows the evolution of U.S. MMF funding vs. ECB funding via long-term refinancing operations (Panel A), and the correlation between banks unsecured flows through U.S. MMFs during the crisis and the amount of LTRO funding received (Panel B).

(a) U.S. MMF vs. ECB funding

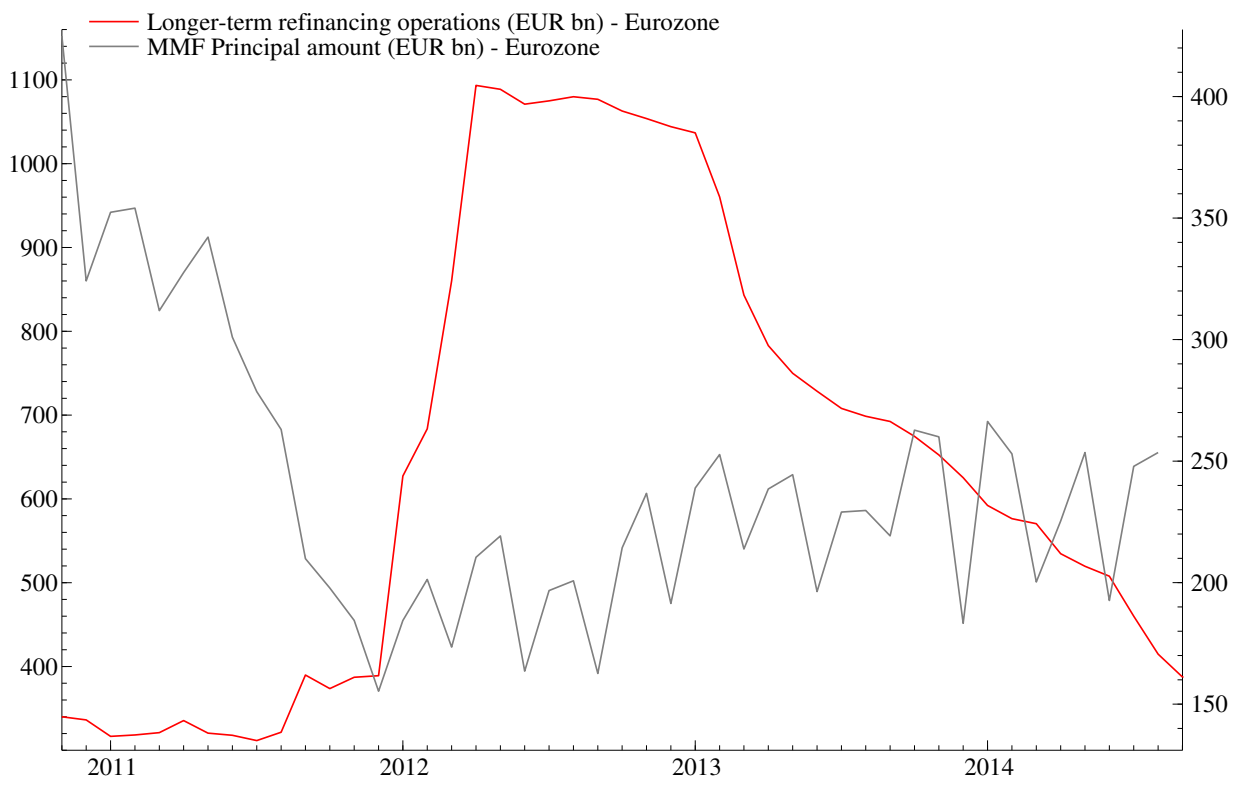

(b) Unsecured U.S. MMF flows against LTRO funding (EUR mn)

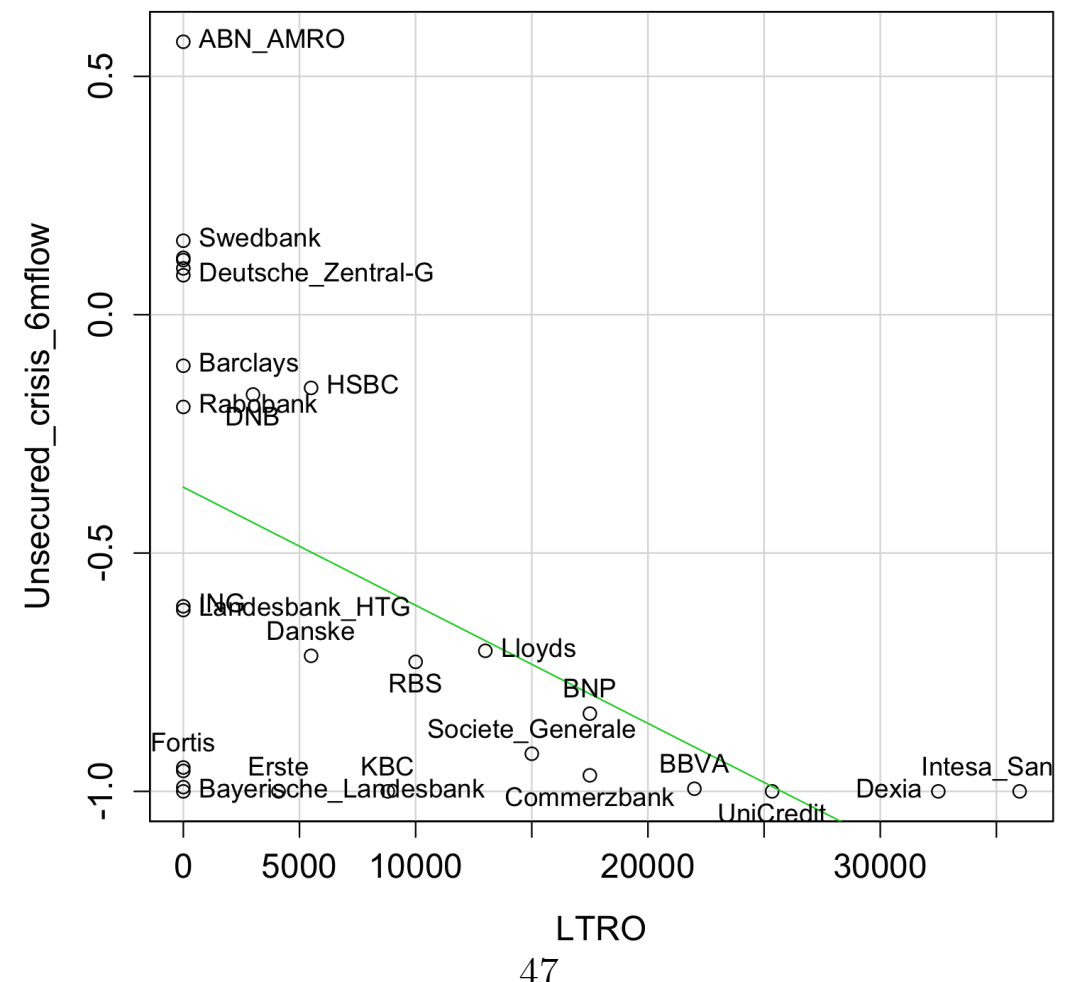

